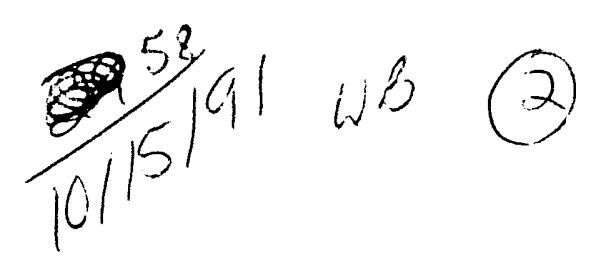

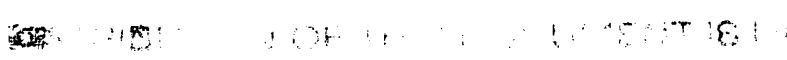





\section{Characterization of Major Waste Data Sources}

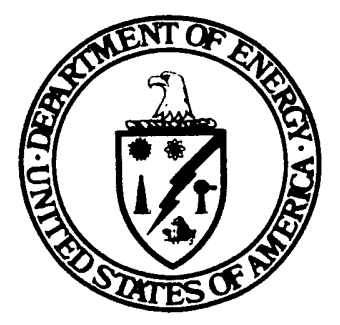

Prepared by :

Richard Cordes and Jack Eisenhauer Energetics, Inc.

7164 Gateway Drive

Columbia, MD 21046

Under Contract \#DE-AC01-87CE40762

Prepared for:

U.S. Department of Energy

Assistant Secretary, Conservation and Renewable Energy

Office of Industrial Technologies

Industrial Waste Reduction Program

Washington, DC 20585

September 3, 1991 
TABLE OF CONTENTS

PREFACE $\ldots \ldots \ldots \ldots \ldots \ldots \ldots \ldots \ldots \ldots \ldots \ldots \ldots \ldots \ldots \ldots \ldots \ldots \ldots \ldots$

EXECUTTVE SWMMARY $\ldots \ldots \ldots \ldots \ldots \ldots \ldots \ldots \ldots \ldots \ldots \ldots \ldots \ldots \ldots \ldots \ldots$ vii

INTRODUCTION $\ldots \ldots \ldots \ldots \ldots \ldots \ldots \ldots \ldots \ldots \ldots \ldots \ldots \ldots \ldots \ldots$

CHARACTERIZATION OF DATA SOURCES $\ldots \ldots \ldots \ldots \ldots \ldots \ldots \ldots \ldots \ldots \ldots$

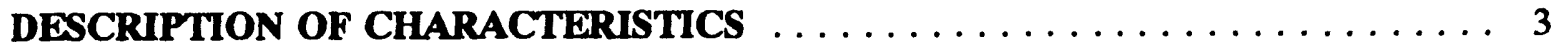

SUMMARY OF DATA SOURCES $\ldots \ldots \ldots \ldots \ldots \ldots \ldots \ldots \ldots \ldots \ldots \ldots$

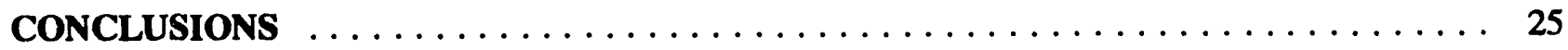

APPENDIX A: DATA SOURCES NOT INCLUDED $\ldots \ldots \ldots \ldots \ldots \ldots \ldots \ldots \ldots$

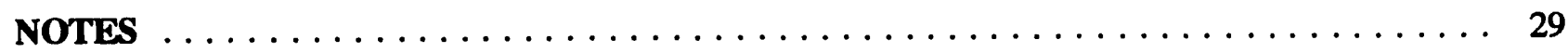

ACRONYMS AND ABBREVIATIONS $\ldots \ldots \ldots \ldots \ldots \ldots \ldots \ldots \ldots \ldots \ldots \ldots$

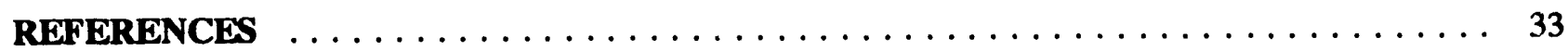




\section{PREFACE}

The U.S. Department of Energy (DOE) recently initiated the Industrial Waste Reduction Program, which seeks to develop and commercialize waste reduction technologies and practices that will reduce industrial energy use. The Industrial Waste Reduction Program, like the other programs under DOE's Office of Industrial Technologies (OIT), works with industry to focus research and development resources according to industry needs and market opportunities. The Program consists of five fundamental elements:

- Industrial Waste Characterization

- Opportunity Assessments

- Technology Research and Development

- Technology and Information Transfer

- Institutional Analysis

This report is a product of efforts initiated under the first of these program elements, Industrial Waste Characterization. Its purpose is to increase understanding of the types and magnitudes of industrial waste streams. In particular, this report presents the key characteristics of selected waste, energy, and economic data sources in an effort to clarify the scope, consistency, and limitations of the data. It is expected that this information will be used in another element of the program, Opportunity Assessments. That effort will identify priority technology needs by evaluating the available data; expert advice from industry, government, and academia; and independent analyses.

The authors wish to thank the organizations for their cooperation and help in acquiring and interpreting the data sources. A special thanks is also owed to Bruce Cranford of DOE's Office of Industrial Technologies for his guidance and support. 


\section{EXECUTIVE SUMMARY}

The data available on waste generation are gathered by a variety of groups for different reasons. This diversity presents obstacles when the data are combined or compared. The problems include differences in data collection and reporting methods, inconsistencies in the definition of waste among sources, and informational gaps in the types of wastes reported.

A first step to understanding and correcting deficiencies in waste data is to identify the major sources of industrial waste data and to examine their key characteristics. This report accomplishes this by characterizing 22 major sources of data on industrial waste and related industrial activity. Of the 22 sources examined, fifteen contain information on industrial waste streams, six cover industrial economic data, and one reports industrial energy consumption. Three of the fifteen waste data sources examined provide information from the same data source but in a slightly different form. Of the twelve primary waste data sources,

- two are non-government surveys,

- two contain estimated values based on sconomic and technical modeling,

- four represent one-time data collection efforts, and

- four are data sets regularly collected by the Environmental Protection Agency (EPA) in compliance with regulatory requirements.

These data provide a starting point from which to assess the industrial generation of waste. Using this group of data presents a number of obstacles, however. For instance,

- The definition of waste is not consistent across the data sources. Although EPA established a well-known legal definition of hazardous solid waste under the Resource Conservation and Recovery Act (RCRA), no single definition of hazardous waste is used by all sources. Typically, "hazardous wastes" will include, in addition to these RCRA-regulated wastes, some wastewaters regulated under the Clean Water Act. Moreover, most of the surveys reporting hazardous wastes do not split out the RCRA-regulated wastes, making comparison to figures reported in EPA's Biennial Report difficult.

- The definitions of solid waste, hazardous waste, and toxic chemical release (which determine which substances are reported) have varied over time; even data collected periodically by the same mechanism (i.e., the Toxics kilease Inventory) refer to a different set of wastes.

- While a number of sources preserit hazardous waste data, no single source presents all releases of all hazardous wastes. The Toxics Release Inventory presents information on releases to air, water, and land for only a limited number of chemicals, rather than for all hazardous wastes. All other reports present releases to a single media: air, water, or land.

- Information on nonhazardous waste is not collected on a regular basis by either the federal government or by industry groups. Most of the information that has been gathered reflects only a snapshot of the conditions at a given point in time. This creates particular problems in assessing 
energy savings opportunities since nonhazardous wastes represent over $95 \%$ of all industrial wastes.

- None of the waste data studied in this report are correlated to production levels.

- Most, but not all, sources present data using the Standard Industrial Classification (SIC) code. The absence of a universal industrial classification system limits the usefulness of some of the data.

Most of the economic information studied was collected by the Bureau of the Census (in the Department of Commerce). Four Census Bureau surveys provide information on different industries (agriculture, mining, construction, and manufacturing), while one presents the environmental costs paid by the manufacturing indusiry. The Bureau of Mines (in the Department of the Interior) publishes a compilation of information on different segments of the minerals industry.

Economic data have been collected periodically for many years, so the methods of collecting and analyzing data have become standardized. However, one major flaw exists with these data: there is no direct measure of industrial output common to all industries. This hinders attempts to correlate waste generation and energy consumption to production.

DOE's Energy Information Administration (EIA) publishes information on the energy consumed by manufacturing industries. The data presented by EIA are detailed, reliable, and consistent. However, the Manufacturing Energy Consumption Survey (MECS) is not particularly timely, as it is published more than iwo years after the data were originally collected.

The data sources examined in this report provide the rudiments necessary to begin an analysis of the opportunities to save energy through waste reduction. However, to fully exploit industrial waste reduction opportunities, additional information will need to be collected. More complete and reliable data will be required to measure progress in waste reduction. 


\section{INTRODUCTION}

Federal and State programs that seek solutions to the Nation's major industrial waste problems are hindered by data that are incomplete, inconsistent, and inappropriate for determining program priorities. Despite such deficiencies, existing data can provide useful information for helping to identify waste reduction opportunities -- provided that the purpose and limitations of the data are fully understood.

The mission of the recently created industrial Waste Reduction Program (IWRP) under the Department of Energy's (DOE's) Office of Industrial Technologies (OIT), is to work in conjunction with industry to develop and commercialize waste reduction technologies and practices that will reduce industrial energy use. Industrial processes that consume much more energy than required (due to heat losses, poor design, etc.) present great energy-saving opportunities. Similarly, processes that generate more waste than needed (off-specification material, unreacted raw materials, etc.) are the most promising candidates for waste reduction activities.

OIT seeks to focus its research and development (R\&D) resources on those technology area that offer the greatest opportunity to save energy and address the greatest needs of industry. To do this, information on waste generation, energy consumption, and economic conditions must be gathered and examined; expert advice from industry, government, and academia must be sought and evaluated; and independent analyses must be performed.

An initial attempt to determine the total amount of waste generated by industry led to the analysis described in this report. What at first seemed to be a simple task quickly became complex. When data from several sources were combined, it became apparent that the wastes were measured in different ways, dissimilar and sometimes overlapping definitions of waste were used, and each study focused on limited number of waste types. The scope of a given collection and analysis effort depended on how the data were to be used.

The difficulties experienced in this endeavor may have been inevitable, since collecting waste data is an arduous task. There is no precise definition of industrial waste; it changes from facility to facility and over time. Also, most data on waste generation and waste management are collected by government agencies as part of their efforts to define and enforce regulations, which siandis in sharp contrast to the comprehensive and consistent manner in which economic and energy data are collected.

In addition, the organizations that collect waste data (notably EPA) are usually interested in quantifying pollution. Pollution, which is harmful to human health or the environment, is a relatively small subset of waste, which includes all unwanted byproducts of an industrial process, harmful or not.

Clearly, much of the information needed to assess opportunities for industrial waste reduction and energy savings is not readily available, or not available in a form that is easily used. Therefore, a preliminary step in using available waste data sources is to determine basic characteristics and the practical limitations to its use. This report is intended to accomplish that step.

To identify the processes within the agriculture, mining, construction, and manufacturing industries that have the greatest potential for energy savings and waste reduction, the following information is desirable: 
- Process-specific energy consumption,

- Process-specific minimum energy requirements (based on thermodynamic analysis),

- Process-specific waste generation, and

- Process-specific minimum waste generation (based on thermodynamic analysis).

These data must also be correlated to a production level. Unfortunately, process-specific information is rare, thermodynamic analyses for most processes are uncommon, and most production information is considered proprietary.

Nevertheless, the following information is usually available:

- Industry-specific energy consumption,

- Industry-specific waste generation, and

- Industry-specific economic data.

With this information, rough estimates can be made of the potential energy-saving and waste-reducing opportunities of different industries. The industries consuming the largest amount of energy and generating the largest amount of waste per unit of output are assumed to offer the greatest opportunities to save energy and reduce waste.

These data also have limitations, however. A few years ago, the Office of 'Technology Assessment (OTA) cited a number of failings exhibited by hazardous waste generation data. ${ }^{1}$ While the scope of this report encompasses nonhazardous as well as hazardous wastes, some of OTA's reasoning still applies. OTA observed that

- Many of the estimates are only for wastes regulated under the Resource Conservation and Recovery Act (RCRA);

- Annual waste generation estimates for the Nation vary widely and must be viewed as highly uncertain;

- Many waste streams contain only a small amount of waste material mixed with water; and

- Waste generation figures are not usually correlated to production.

Furthermore, the available data on energy, production, and associated costs are alsc subject to various limitations. Energy data are recorded primarily for the consumption of oil, natural gas, coal and electricity, but the use of biomass-derived energy is not well described, The economic data are limited by their subject matter. And because different industries create different products, no direct measure of output is common to all industries.

Still, the data can be used if the limitations are recognized. This report seeks to highlight these limitations, particularly for the waste data. Eleven selected characteristics are used to describe 22 data sources, including 15 waste data sources, six economic data sources, and one energy data source. This analysis is intended to serve as a "road map" to using these data sources for assessing industrial waste reduction and energy saving opportunities. 


\section{CHARACTERIZATION OF DATA SOURCES}

Data are collected by various groups and for many purposes; this diversity affects how the data are generated and reported. These variations can lead to problems when more than one source of data is used. For instance, a number of documents report industrial waste generation or waste management information. While these documents may outwardly appear to include the same information, the data may not agree very well; there is a lack of consistency and uniformity. This report defines the bounds of the information contained in the major data sources currently. It may be used to guide waste data users to the data to the most appropriate source.

To help drivers understand a road map, a legend or set of symbols is included. In this report, the Description of Characteristics serves that purpose. It explains the type of information provided in vach report. Extending the analogy, the Summary of Data Sources then serves as the map to the data sources. The text highlights noteworthy attributes, while the tables contain detailed information.

\section{DESCRIPTION OF CHARACTERISTICS}

The eleven characteristics chosen to describe the data sources are shown in Exhibit 1. The first five characteristics (descriptive characteristics) provide general information that is helpful in locating and gaining access to the data; the last six (technical characteristics) furnish essential facts on the limitations and potential uses of the data. Each of the characteristics is described below.

\section{Responsible Organization and Contact}

Knowing the identity of the organization responsible for the collection and analysis of the data can be an aid to determining the reason the data were collected and may suggest the type of information reported. The data sources examined in this report were all generated or supported by national trade associations or various agencies of the

\section{Exhiblt 1. Data Chamateristics}

1. Responsible Organization and Contact

2. Date of lssue

3. Accessibility

4. Age of Data

5. Collection Frequency

6. Information Reported

7. Reporting Commanily

8. Collection Method

1. Reporting Requirement

10. Measurement Characteristic

11. Measurement Basis (for wastes)

Federal government. The Environmental Protection Agency (EPA), in particular, produced many of these studies. Since EPA focuses on pollution, its studies tend to yield data on the amount of pollutants treated or released to the environment, the hazards they present to human health and the environment, and handling methods. Because EPA's needs differ from those of DOE, the information is not always presented in a form that is useful to this Program.

The name, address, and phone number of a contact person is provided for each data set. The contact should be able to answer questions about the data, and help interested individuals gain access to the information. The name and number of the contact is current as of the release of this report, but is subject to change over time. 


\section{Date of Issue}

When data are published, the information is usually fairly up-to-date. In some cases, however, older data collections are published because the wider value of the data had not been previously recognized, or because the data required thorough, time-consuming analysis before they could be published.

\section{Accessibility}

This report examined two forms of data sources, documents (hard copies) and computer databases. Most of these sources are availabie to the public. The one exception is the document, Results of the Industrial Subtitle D Facility Survey; ${ }^{2}$ however, these results are presented in the Report to Congress: Solid Waste Disposal in the United States. ${ }^{3}$

All other documents are available for i fee, many from the National Technical Information Service or the Government Printing Office. Fees may also be charged for on-line access to the databases, or for printouts received under Freedom of Information Act (FOIA) filings.

\section{Age of Data}

To prepare an overall picture of waste stream data, information from different types of data from the same period should be used to the maximum extent possible. Because the year in which a report is released often lags by two years the date of collection, the age of the data is a critical feature. The lag time may be even longer for studies that are the first in a series or that are conducted for a special purpose. This category also indicates whether the report contains data from more than one year.

\section{Collection Frequency}

Surveys conducted on a regular basis are needed to obtain the data necrecary to assess progress in reducing wastes. This is because data may also reflect trends in economic activity and energy consumption, independent of waste reduction activities. Data issued on a one-time basis provide only a snapshot of waste generation activity. It may be difficult to determine whether conditions extant at the time of data collection are typical or abnormal.

\section{Information Reported}

This characteristic describes the type of waste, energy, or economic information that is covered in the data source. The information may be restricted by the types of wastes surveyed, the manner in which the wastc s are managed, or the industries responsible for producing the waste. Restrictions on economic or energy data are also noted.

\section{Reporting Community}

The reporting community describes the set of facilities or industries from which the data are collected. This is typically broken down by industry, but other attributes are also used, such as the function of the facility (e.g., waste generator) or its regulatory status (RCRA-regulated treatment facility). 


\section{Reporting Requirement}

Under some sections of Federal law, facilities may be required to report economic, energy, and environmental information. Most of the data collected for or by the Federal government were collected under these requirements. Knowing the applicable reporting requirement can help data users identify why the data were collected and, therefore, what kind of information might be included.

\section{Collection Method}

The methods by which data are collected provide valuable insight into the coverage and reliability of the data. Some reports provide waste estimates based on economic activity, while other studies rely on facilities to self-report the desired information. In some cases, occasional site visits by investigating personnel are used to confirm reported data.

One of the best data collection methods would be to have a trained survey team physically measure the waste generated by each facility (2; process). Use of the same trained survey team at all facilities would help to ensure a comprehensive and consistent source of data. Realistically, however, none of the reports examined here used such a method. As a result, the quality and consistency of the data may be variable.

\section{Measurement Characteristic}

The stage at which waste data are collected can greatly affect the amount and type of waste reported. The data may reflect piocess wastes, overall plant wastes, or even industry or nationwide wastes.

Process wastes may be recyclet or altered physically or chemically on the plant site, changing the form or amount of waste. For example, a facility that recycles many of its wastes on-site could report either of two values. One would be the waste generated by the process, while the other would be the waste treated, stored, discarded, or sent off-site. The measurement characteristic indicates which value was reported.

\section{Measurement Basis}

Wastes are often mixer with water or other materials when released. The measurement basis indicates whether the wastes are reported as separated entities (on a constituent basis) or as a combined stream (on a waste basis). When the amount of wastes listed in the source includes some weight or volume of water, the wastes are considered wet wastes. When only the amount of a certain species is reported (with no measurement of water), they are dry wastes.

These characteristics illustrate the range of information provided by the data sources, and help to indicate potential difficulties in combining or comparing data.

\section{SUMMARY OF DATA SOURCES}

No single source presents all the information required to determine the best industrial waste reduction opportunities. To create a complete picture of industrial discharges, emissions and releases, the economic conditions, and the energy consumption, many different sources are required. 
The data sources included in this report are primary sources that are national in scope. An attempt was made to cover all industries and forms of waste included under the IWRP. The data reported in secondary sources have sometimes been manipulated to serve purposes other than those for which they were originally collected; for this reason, they may be less reliable than the primary data. The 22 sources studied in this report are shown in Exhibit 2, as are the abbreviations used for the data sources in the remainder of this document. For a complete citation of each source, see the References provided at the end of this document.

Deta".ed analyses of these data sources are provided in Exhibits 3 and 4 . Exhibit 3 contains the descriptive characteristics of each source, the information needed to acquire or access the data. Exhibit 4 displays the technical characteristics of the each data source.

\section{Waste Data}

It is difficult to determine what materials are wastes, as some byproducts from processes are later utilized to generate other products. It is also difficult to classify wastes. One complication is that wastes are typically classified or defined for legal reasons; the classifications are based on the risks the materials present, rather than on strict physical properties.

The generation and management of wastes are governed by the Environmental Protection Agency (EPA) under several laws. Solid wastes (including hazardous solid wastes) are regulated under the Resource Conservation and Recovery Act (RCRA), air emissions are governed under the Clean Air Act, and water discharges are regulated under the Clean Water Act. The regulations promulgated under these laws also define the wastes covered by the law.

Fifteen sources present data on waste generation, management, or releases. The three major categories (solid wastes, air emissions, and water discharges) were used to classify i hese data sources. Eleven data sources report information on releases of solid wastes (eight hazardous, three nonhazardous or "excluded"), one source reports discharges to water, and three report air emissions. However, some data sources "overflow" their categories, containing wastes from more than one ilassification. For example, changes in EPA's hazardous wastes classification have caused substances once considered nonhazardous wastes to be included in the hazardous wastes category. In addition, the constituents of a category can be altered. Changes in laws or regulations often add or remove substances from the lists of water or air pollutants.

Hazardous solid waste. The Resource Conservation and Recovery Act (RCRA) was enacted to address and curtail the hazardous wastes discarded on land. The Act defines solid waste and further specifies a subcategory of hazardous waste (Subtitle $\mathrm{C}$ wastes). EPA is authorized to regulate the generators and handlers of solid wastes, including hazardous solid wastes.

The largest number of data sources describe facets of the hazardous waste universe. Six documents and two databases that report hazardous waste information were investigated. Many of these documents and databases originate with EPA.

Trade associations representing highly regulated industries (chemicals and petroleum refining) also produce reports. Their information includes some nonhazardous wastes. 


\section{Exhlbit 2. Sources of Industrial W'ste, Economle, and Fnergy Data}

1. The Generation and Management of Wastes and Secondary Materials in the Petroleum Refining Industry: 1987-1988 (APISur)

2. CMA Hazardons Waste Survey 88 (CMASur)

3. 1985 National Biennial Report of Hazardous Waste Treatment, Storage, and Disposal Facilities Regulated under RCRA (BR)

4. National Survey of Hazardous Waste Generators and Treatment, Storage, Disposal, and Recycling Facilities, 1986 (NatSur) $^{3}$

5. Hazandous Waste Management: Recent Changes and Policy Alternatives (CBOEat)

6. Biennial Repont System (BRS)

7. National Air Pollutant Emission Estimates; $1940-1989$ (NAPRE) $^{3}$

8. Current Emission Trends for Nitrogen Oxides, Sulfur Dioxide, and Volatile Organic Compounds by Month and State: Methodology and Results (MSCET)

9. Aerometric Information Retrieval System (AIRS)

10. Permit Compliance System $(\mathbf{P C S})^{5}$

11. Toxics in the Community: National and Local Perspectives (IRISar) ${ }^{3}$

12. Toxics Release Inventory (TOXNET)

13. Report to Congress on Special Wastes irom Mineral Processing (SMP)

14. Report to Congress: Management of Wastes from the Exploration, Development, and Production of Crude Oil, Natural Gas, and Geothermal Energy. Volume 1. Oil and Gas. (O\&G)

15. Screening Survey of Industrial Subtitle D Establishments: Draft Final Report (SubD) ${ }^{3}$

16. Manufacturers' Pollution Abatement Capital Expenditures and Operating Costs: Final Report for 1988 (PACE) $)^{8}$

17. Minerals Yearbook 1988. Volume 1. Metals and Minerals. (MinY)

18. 1987 Census of Agriculture (AgCen)

19. 1987 Census of Construction Industries (CanCen) ${ }^{8}$

20. 1987 Census of Manufactares - Industry Series (ManCen)

21. 1987 Census of Mineral Industries (Mincen)

22. Manufacturing Energy Consumption Survey: Consumption of Energy, 1985 (MECS) $^{10}$

1 Published by the Amertcan Potroleum Instfute.

2 Published by the Chemical Manufacturers Association.

3 Published by the Envirommental Protection Agency.

4 Published by the Congressional Budget Office.

5 On-line database operated by the Environmental Protection Agency.

6 Publisbed by the Departmeat of Energy's Argonne Natlonal Laboratory.

7 On-line database operated by the National Library of Medicine.

- Published by the Department of Commerce's Bureau of the Census.

9 Publishod by the Department of Interior's Bureau of Mines.

10 Published by the Depatinent of Bnergy's Energy Information Administration. 
Published in 1991, the 1987 National Biennial Report of Hazardous Waste Generators and Treatment, Storage, and Disposal Facilities ${ }^{4}$ is the most recent version of EPA's biennial report. This document presents the waste generation and management practices of generators of RCRA- or state-defined hazardous waste and the treatment, storage, and disposal facilities (TSDFs, which may also generate wastes) that handle these wastes. By law, generators and TSDFs must notify EPA of their activities; generators report the amount of hazardous solid waste they generate, while the TSDFs report the amounts of hazardous solid waste they receive from generators and how the waste is handled. The amounts generated can be separated according to Standard Industrial Classification (SIC) code.

EPA engaged the Research Triangle Institute to conduct the National Survey of Hazardous Waste Generators and Treatment, Storage, Disposal, and Recycling Facilities, 1986. ${ }^{5}$ This was a one-time survey of facilities generating or managing hazardous waste. These facilities report in detail the types of wastes generated and the types of treatment, storage, disposal, or recycling methods used. In addition to containing more detailed information the BRS, this survey is also broader. The Naticnal Survey encompassed non-RCRA hazardous wastes as well as the RCRA Subtitle C wastes included in the BRS. Many of these wastes were wastewaters discharged under the Clean Water Act.

The Chemical Manufacturers' Association published the CMA Hazardous Waste Survey '886 in 1990. Restricted to the chemical manufacturing industry (SIC code 2800), the study includes information on waste activities in 582 U.S. chemical plants, representing 77 companies, that chose to respond to this voluntary survey. In this report, hazardous wastes include those regulated under RCRA Subtitle $C$ as well as other hazardous wastes. Some discharges made under the National Fermit Discharge Elimination System (NPDES) permits, sent to Publicly Owned Treatment Works, or injected underground are included. The results are presented for the reporting facilities only; no attempt was made to convert them to national figures.

The CMA survey has been conducted annually since 1981, and the latest report provides a historical look at the generation and handling of hazardous wastes. In recent years, CMA has included questions on recycling and the management of nonhazardous waste.

Another trade association, the American Petroleum Institute, surveyed the waste generation and management habits of its petroleum refining members (SIC code 2911). A majority of the domestic refineries (115 of 176), representing $80 \%$ of the U.S. crude refining capacity, responded to the survey. The results were published in 1991 in the document The Generation and Management of Wastes and Secondary Materials in the Petroleum Refining Industry: 1987-1988. ${ }^{7}$ The voluntary respondents to this survey indicated the amo ints of wastes they generate and those eliminated by recycle, treatment, and disposal. They also provided information on their source reduction practices. The results from this sample were extrapolated to account for non-respondents. Because data from both 1987 and 1988 are recorded, comparisons between the years are easy to make. A previous survey was also conducted in 1981.

The Toxics Release Inventory (TRI) contains data on more that just hazardous solid wastes. Under the Emergency Planning and Community Right-to-Know Act, manufacturers (SIC codes 20 through 39) are required to report all releases of toxic chemicals (including air emissions and discharges to water), and how these wastes are managed. Most of the chemicals included in TRI are hazardous, but the amounts released are reported on a constituent basis, while EPA's Biennial Report presents the amount of the entire 
waste stream. The data thus collected constitute the TRI, which is published annually by EPA. In 1990, the 1988 data were published in Toxics in the Community: National and Local Perspectives. ${ }^{8}$

Though limited in scope both by the industries required to report and by the chemicals regarded as toxic, TRI is unique in providing a multi-media view of chemical releases. It is probably the best available source for examining waste reduction progress. Its usefulness is restricted, however, because the chemicals included in TRI vary from year to year as the definition of "toxic chemical" changes. Although companies may voluntarily include the details of their recycling and waste minimization efforts, only about $10 \%$ of the manufacturers now do so. The Pollution Prevention Act of 1990, however, requires that manufacturers report detailed information in the future.

Estimates of the amounts of hazardous wastes generated in 1983 were produced by the Congressional Budget Office (CBO) for its 1985 report, Hazardous Waste Management: Recent Changes and Policy Alternatives. ${ }^{9}$ Drawing on economic data and correlations between industrial output and hazardous waste generation, CBO modeled the generation of 24 waste categories in each state for the 70 industries generating the most waste. Its aggregate total for hazardous wastes agrees fairly well with figures reported in EPA studies.

Two computerized databases also record information on hazardous wastes: $B R S$ and TOXNET. Generators of RCRA-defined hazardous waste and TSDFs that handle these wastes report their waste management practices to the Biennial Reporting System (BRS). From the data collected for the BRS, EPA generates the Biennial Report.

The National Library of Medicine's on-line database, TOXNET, contains TRI. It provides information on the amounts of toxic chemicals released by the manufacturing industry, and how these wastes are managed.

The information in each of these databases is more current than that available from printed sources. Freedom of Information Act (FOIA) requests structured to meet the needs of the individual may be placed through the operators of these databases.

Nonhazardous solid wastes and "excluded" wastes. Three documents cover industrial Subtitle D wastes; oil and gas extraction, development, and production wastes; and mineral processing wastes. Subtitle D wastes (also referred to as nonhazardous solid wastes) are RCRA-defined solid wastes that do not exhibit hazardous traits or that have been exempted from being defined as hazardous wastes. Congress also excluded some other wastes because of the possible adverse economic effects on certain industries (oil and gas exploration, mining, mineral processing). EPA has conducted several studies to determine if some types of excluded wastes should be subject to the regulations covering hazardous wastes. Three of these studies are described below. All of them are one-time reports.

The Screening Survey of Industrial Subtitle D Establishments ${ }^{10}$ investigated the practices of facilities that managed RCRA Subtitle D industrial wastes. A statistical sample of these facilities was examined; over 15,000 facilities were surveyed. With the information gathered, EPA estimated the amount of Subtitle $D$ industrial waste generated nationally. This total was broken down into estimates for seventeen industries. Published in 1987, the data in the report reflect 1985 practices. (The results of this survey were summarized in EPA's Report to Congress: Solid Waste Disposal in the United States. ${ }^{11}$ ) 
Another EPA document, Report to Congress: Management of Wastes from the Exploration, Development, and Proluction of Crude Oil, Natural Gas, and Geothermal Energy, ${ }^{12}$ reports estimates of the drilling wastes and produced water generated by onshore drilling for crude oil and natural gas in 1985. The estimates in this 1987 report are based on field samples, literature searches, and conversations with state regulatory personnel. The document also reports an assessment of the risks presented by these wastes.

EPA's 1990 Report to Congress on Special Wastes from Mineral Processing ${ }^{13}$ contains data on waste streams that are considered potentially hazardous. In 1989, EPA contacted 200 facilities for information on the generation and management of 20 specific wastes from the processing of twelve mineral commodities. EPA also conducted tests to determine the hazards that these wastes presented.

Air emissions. Two reports provide air emission estimates. One document provide nationwide estimates, while the other contains state-by-state estimates. In addition, an EPA database provides more specific information on emission from industries and from processes.

Both reports (EPA's National Air Pollutant Emission Estimates: 1940-1989 14 and Argonne National Laboratory's (ANL's) Current Emission Trends for Nitrogen Oxides, Sulfur Dioxide, and Volatile Organic Compounds by Month and State: Methodology and Results ${ }^{15}$ ) present national estimates of three emissions: nitrogen oxides $\left(\mathrm{NO}_{\mathrm{X}}\right)$, sulfur dioxide $\left(\mathrm{SO}_{2}\right)$, and volatile organic compounds (VOCs). EPA also estimates the amouni of particulates, carbon monoxide $(\mathrm{CO})$, and lead $(\mathrm{Pb})$ released into the atmosphere. The EPA document was published in 1991. and includes estimates for 1989.

The data in ANL's 1990 document are broken down into regional and statewide emissions and are also available by month. The Month and State Current Emission Trends (MSCET) document incorporates the National Air Precipitation Assessment Program (NAPAP) Emissions Inventory, data from EIA, ${ }^{16}$ and figures from the Department of Commerce. ${ }^{17}$

The Aerometric Information Retrieval System (AIRS) database, operated by EPA, includes emissions and compliance data for six priority pollutants $\left(\mathrm{NO}_{\mathrm{X}}, \mathrm{SO}_{2}, \mathrm{VOCs}, \mathrm{CO}, \mathrm{Pb}\right.$, and particulates). Emission data are available by SIC code and for 5,000 industrial processes. FOIA requests may be placed through the operators of the AIRS database. The National Air Pollutant Emission Estimates are drawn from the AIRS database.

Water discharges. EPA operates a database containing records of permitted discharges from point sources, including industrial facilities. The Permit Compliance System (PCS) is a computerized management system for tracking permit, compliance, and enforcement status for the National Pollutant Discharge Elimination System (NPDES) under the Clean Water Act. FOIA requests made to EPA can provide the amount of pollutants discharged by facilities throughout the nation.

\section{Economic Data}

Every five years, the U.S. Bureau of the Census gathers detailed information on the U.S. economy. The last year for which such data were collected was 1987. Based on these data, reports on four broad industrial sectors were produced. They include the Census of Agriculture, ${ }^{18}$ Census of Construction Industries, ${ }^{19}$ Census of Mineral Industries, ${ }^{20}$ and Census of anufactures - Industry Series. ${ }^{21}$ Together, these reports cover most of the industries with SIC codes 1 through 39. 
These reports indicate the level of economic activity in the different sectors. For example, harvests, yields, and value of products are listed in the agricultural census; it also contains information on chemical use and petroleum consumption. The report on the mining industry includes the value of shipments, capital expenditures, and fuel consumption. This information can be supplemented with data provided in the Bureau of Mines' Minerals Yearbook. ${ }^{22}$ Among the facts reported in the latter publication are the amount of minerals and metals produced and consumed.

The Census Bureau also produces the Manufacturers' Pollution Abatement Capital Expenditures and Operating Costs. ${ }^{23}$ Costs are broken down by industry (two- and four-digit SIC codes) and by the waste media (air, water, or solid -- including hazardous -- waste). These data, while valuable, do not provide measures of output in a unit common to all industries. Two factors, value added and employment, are collected industrywide and might be used in the absence of this measure. Because the values of each depend on many factors, including but not limited to the energy efficiency or waste generation of operations, using either will provide only a crude measure of actual output.

\section{Energy Data}

DOE's Energy Information Administration (EIA) publishes the main source of energy data examined in this report, the Manufacturing Energy Consumption Survey. ${ }^{24}$ Data for this report are gathered every three years. Restricted to SIC codes 20 through 39 (manufacturing), this source reports energy consumption data for each industry, by the form of energy used (i.e., natural gas or electricity).

Clearly, the 22 data sources examined in this report present valuable information that can be exploited to assess possible targets for waste reduction. With an increased understanding of the contents and limitations of each data set, DOE can more confidently pursue its Opportunity Assessments activities. 


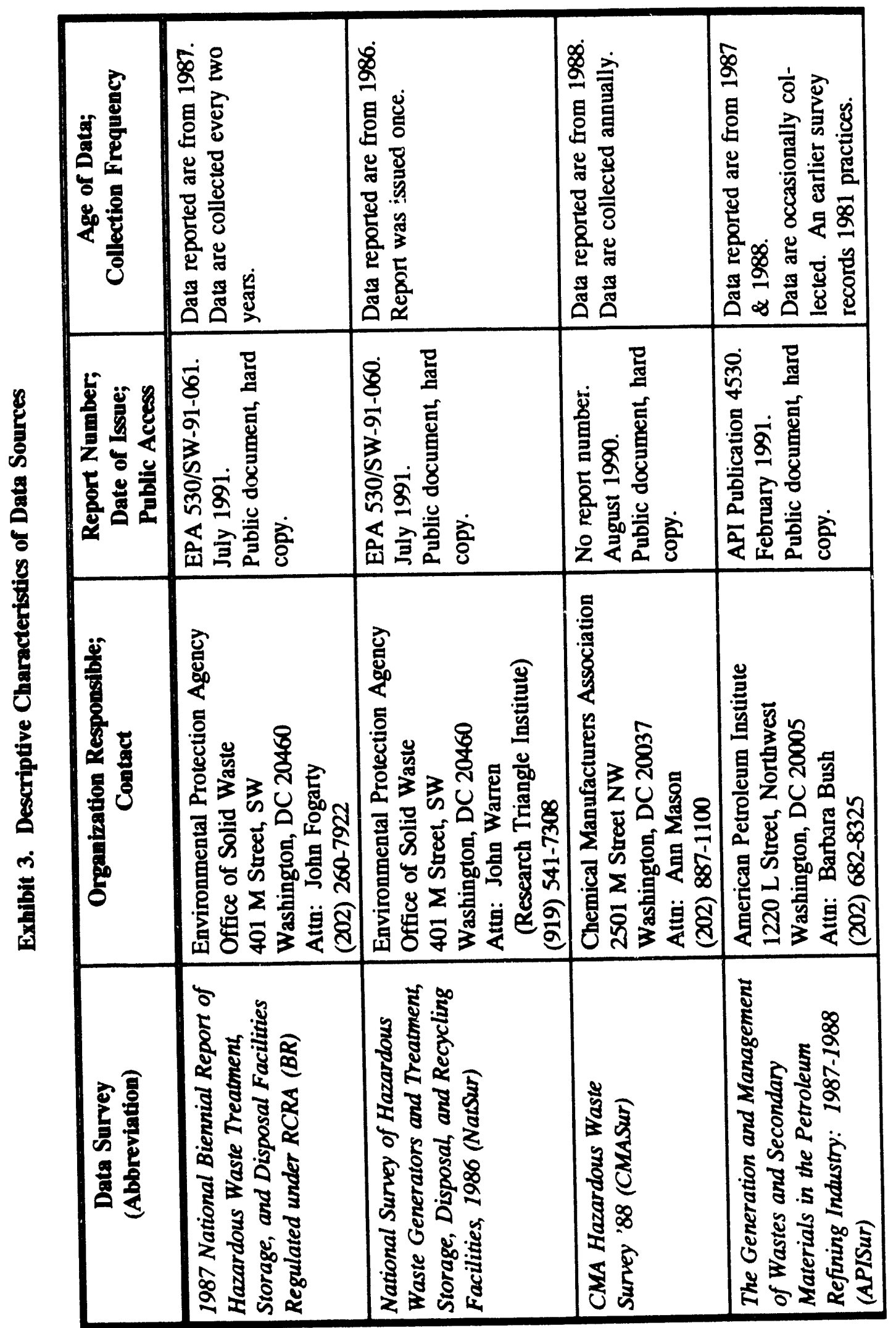




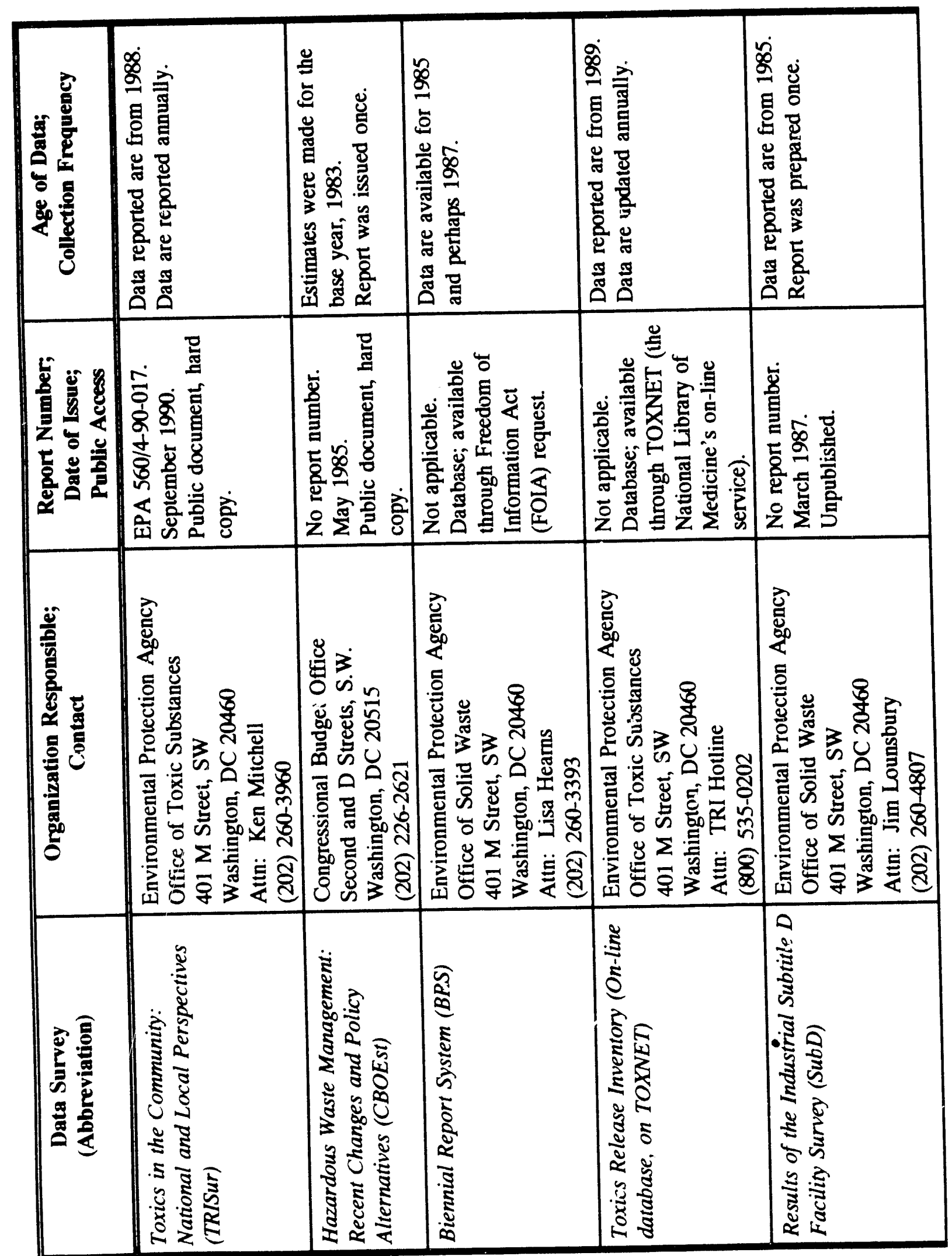

Characterization of Waste Data Sources 


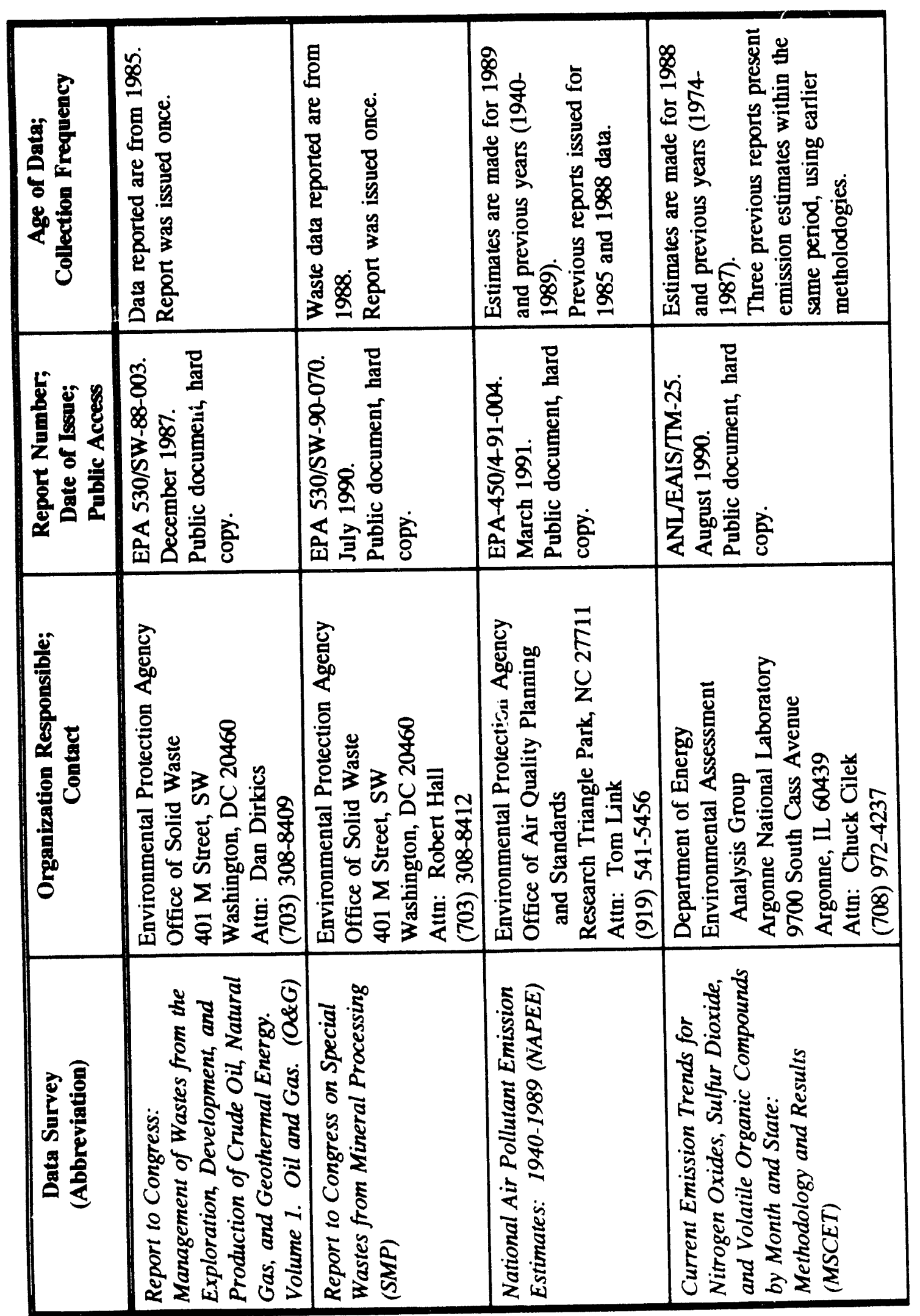

Characterization of Waste Data Sources 


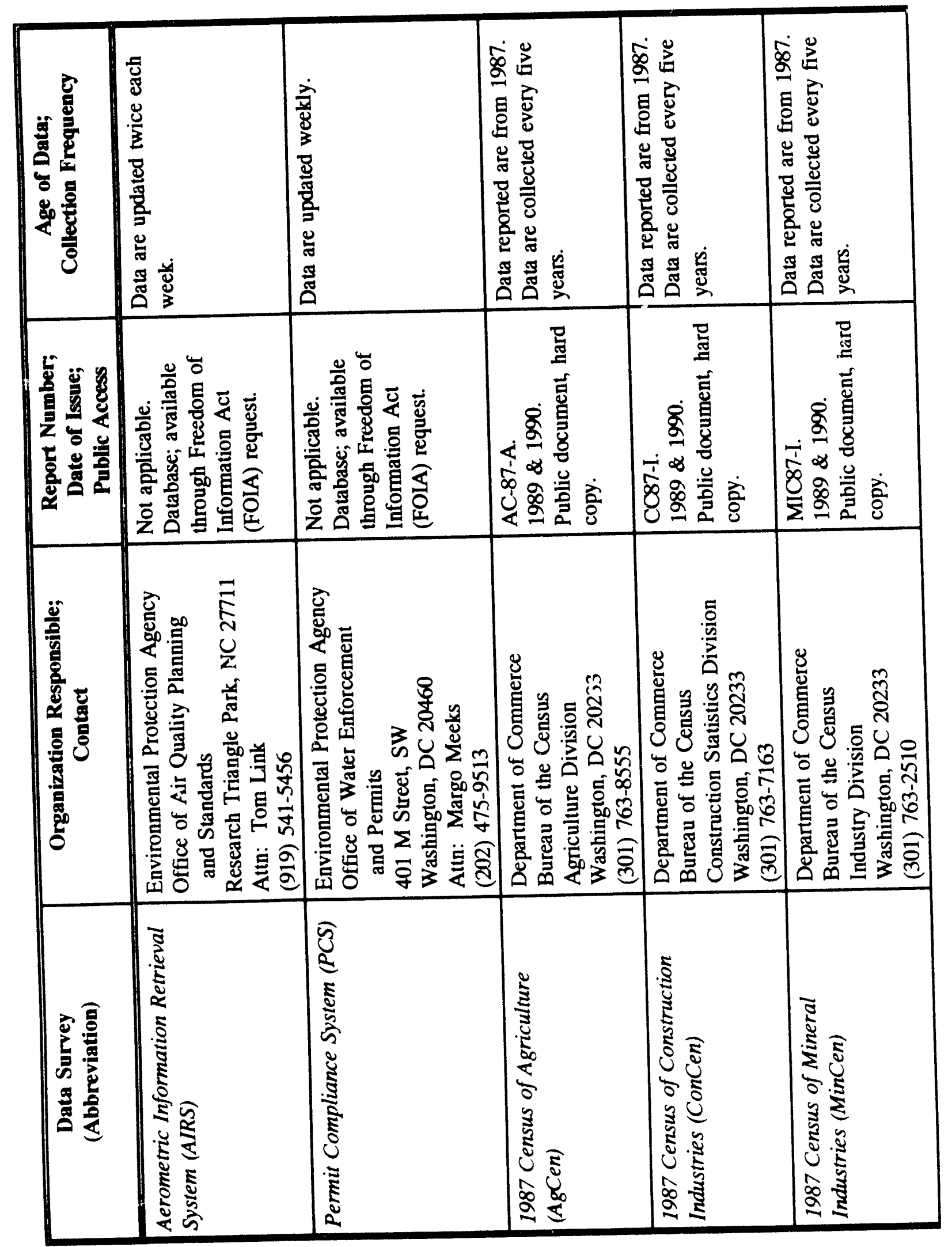




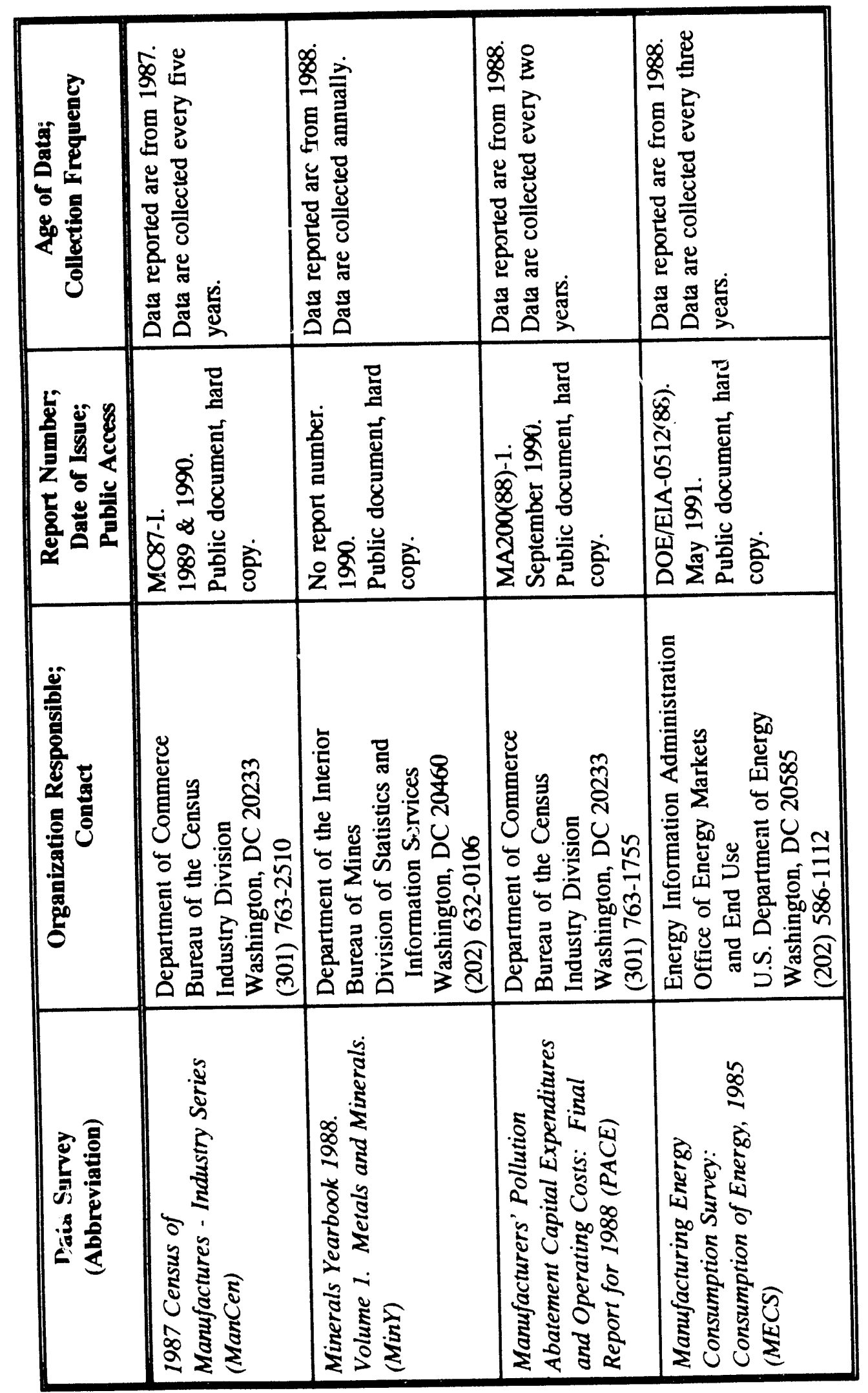

Characterization of Waste Data Sources

16

September 3, 1991 


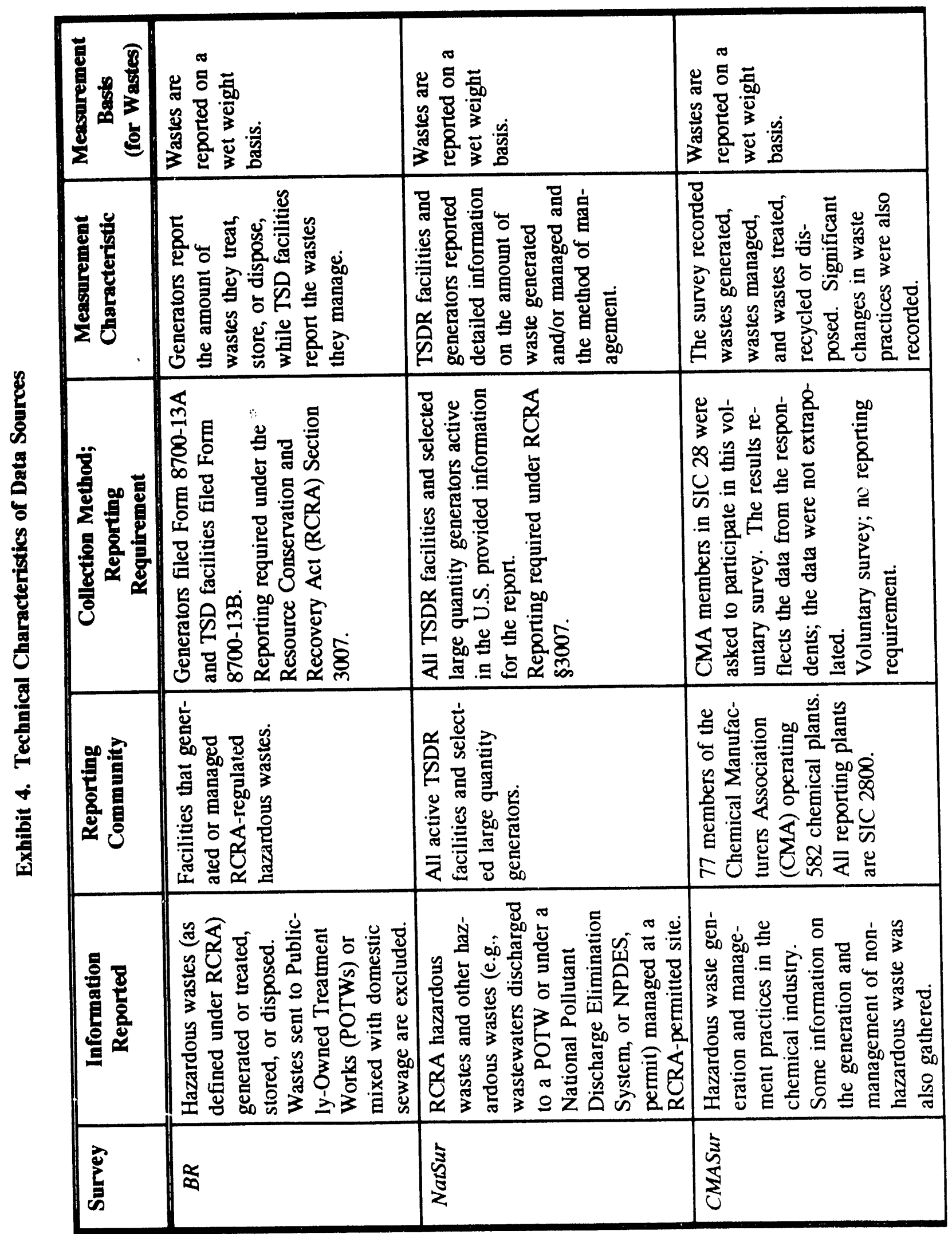




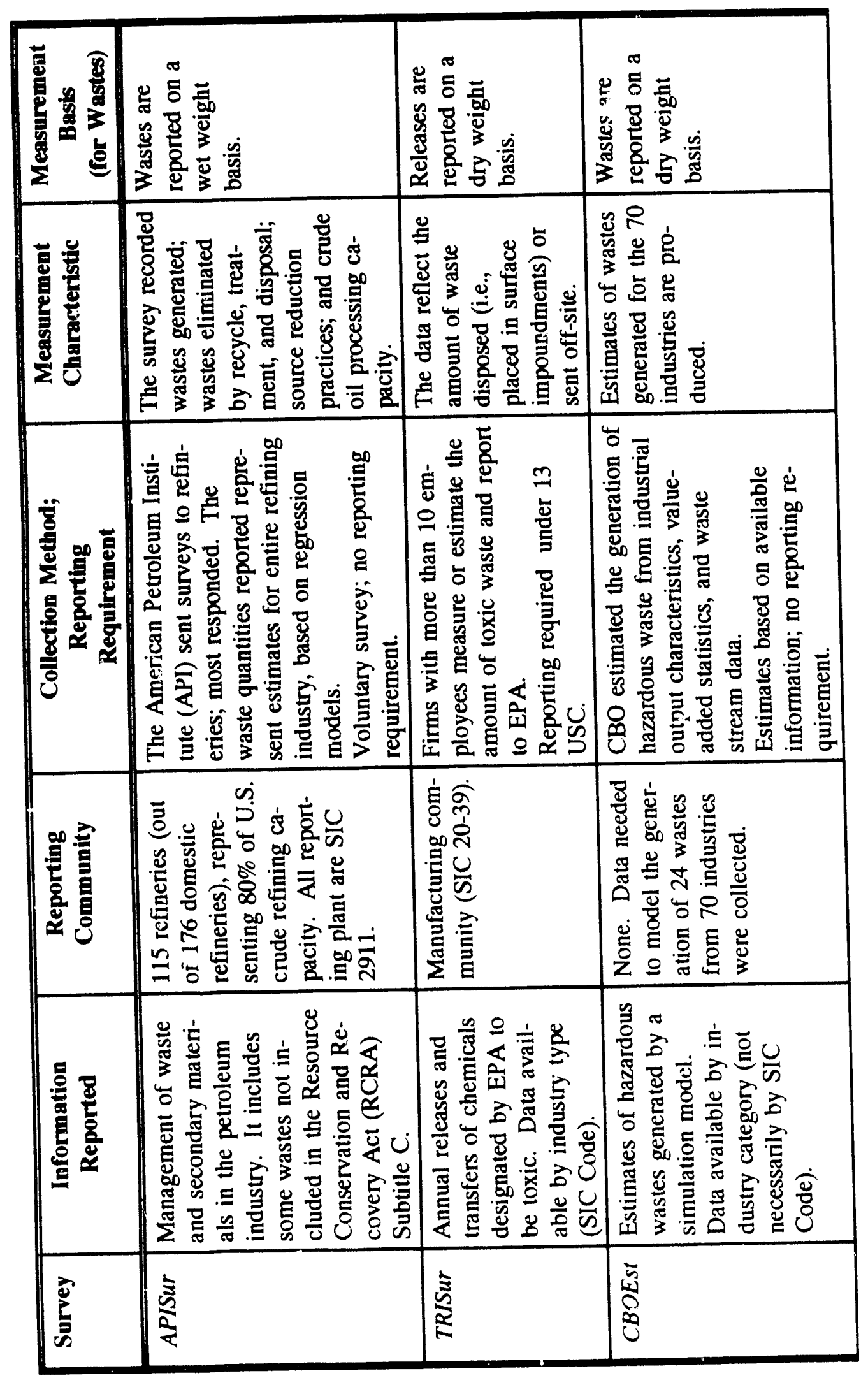

Characterization of Waste Data Sources 


\begin{tabular}{|c|c|c|c|}
\hline 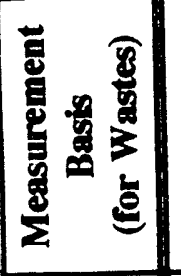 & 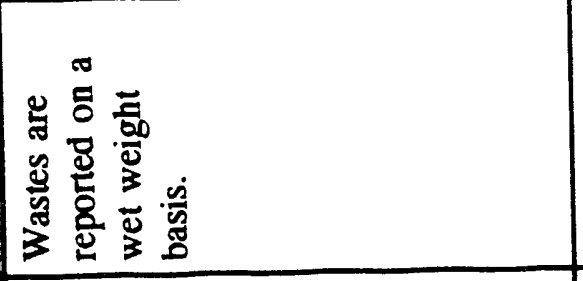 & 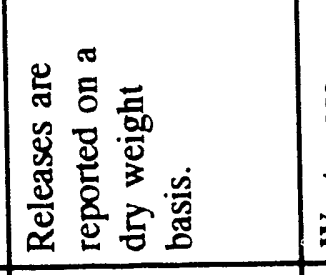 & 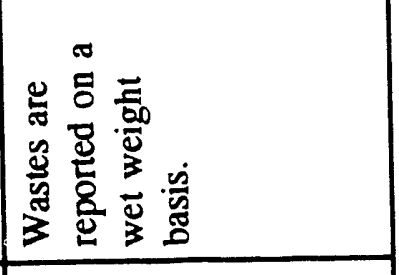 \\
\hline 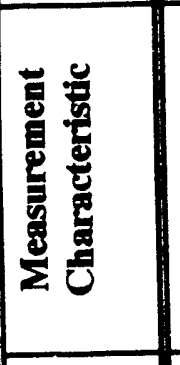 & 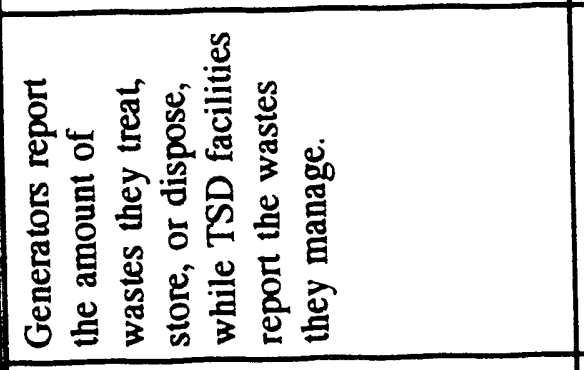 & 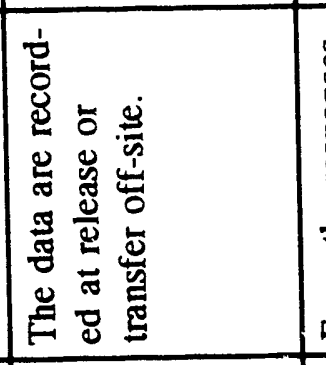 & 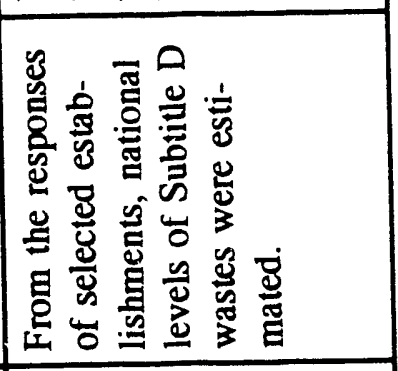 \\
\hline 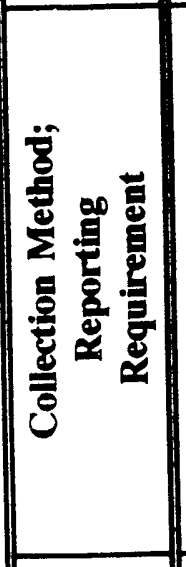 & 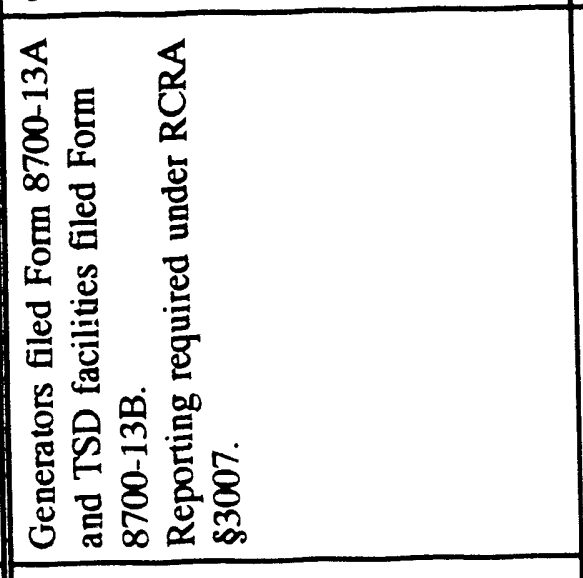 & 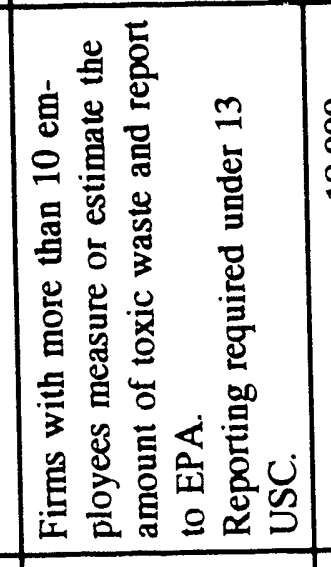 & 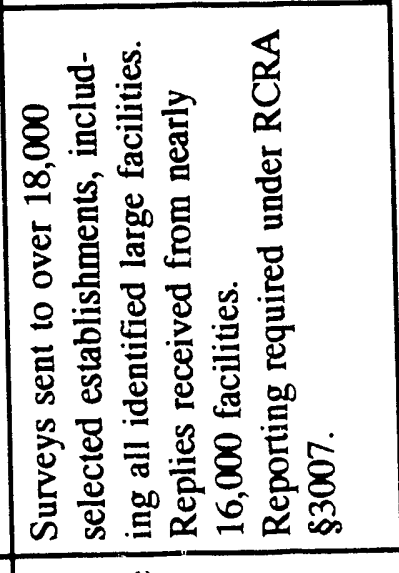 \\
\hline 骂 & 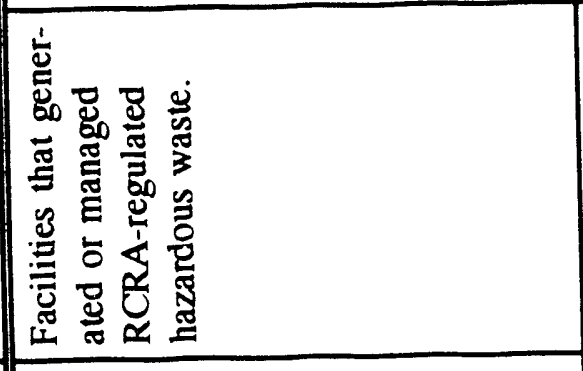 & 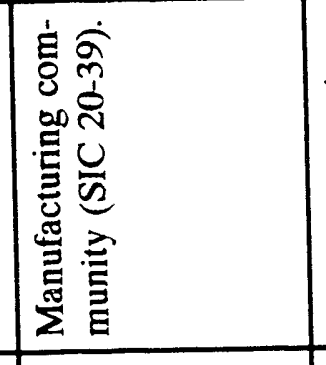 & 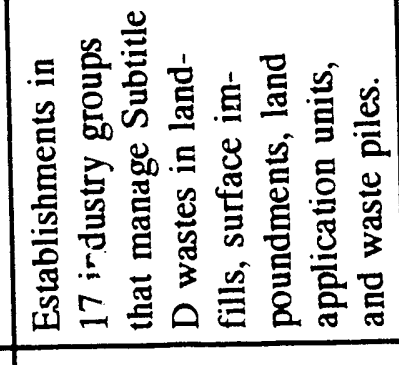 \\
\hline 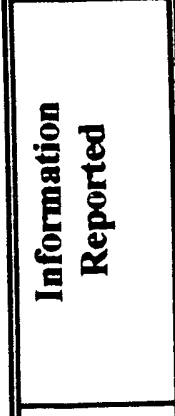 & 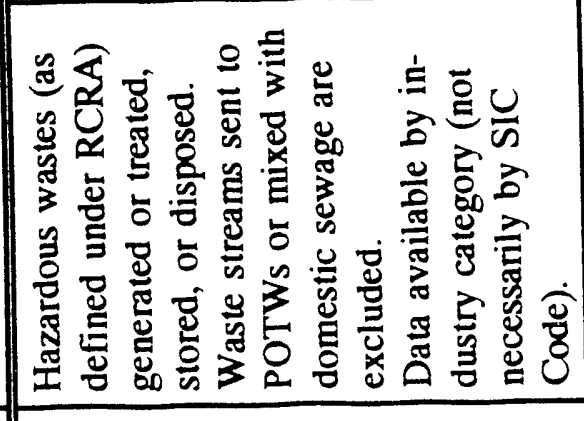 & 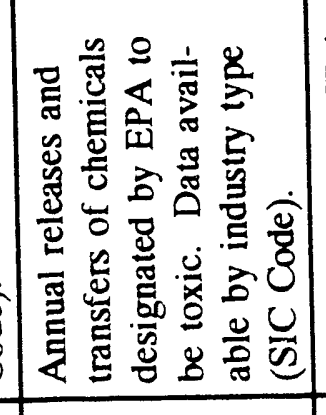 & 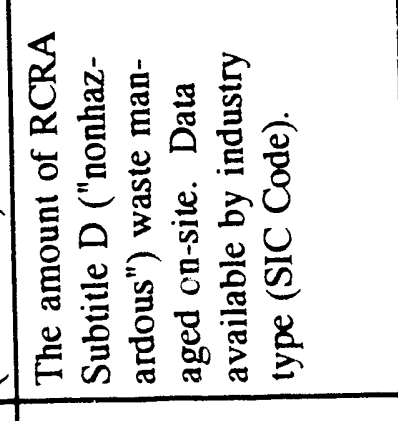 \\
\hline 密 & $\frac{z}{2}$ & 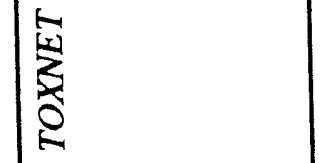 & 离 \\
\hline
\end{tabular}




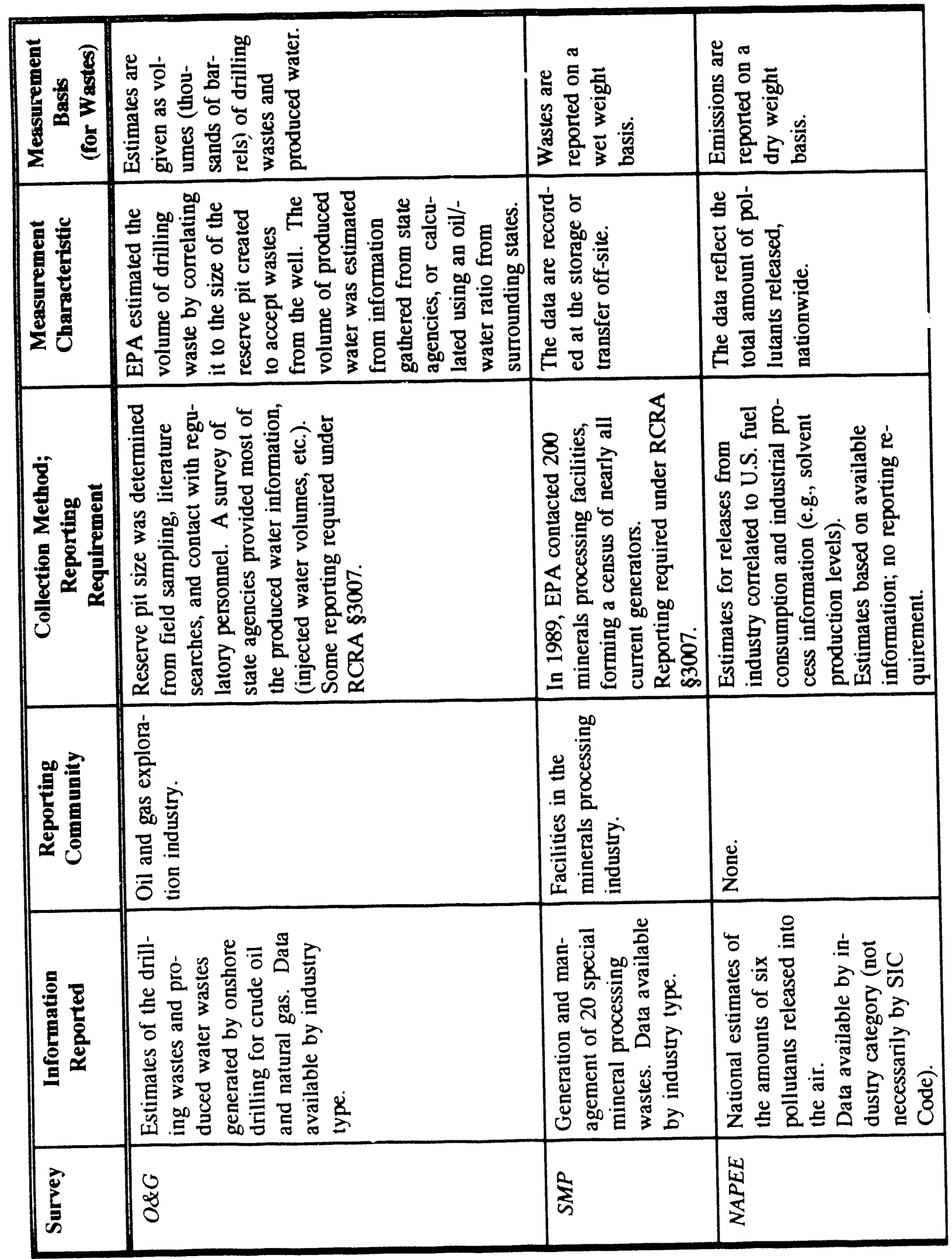

Characterization of Waste Data Sources 


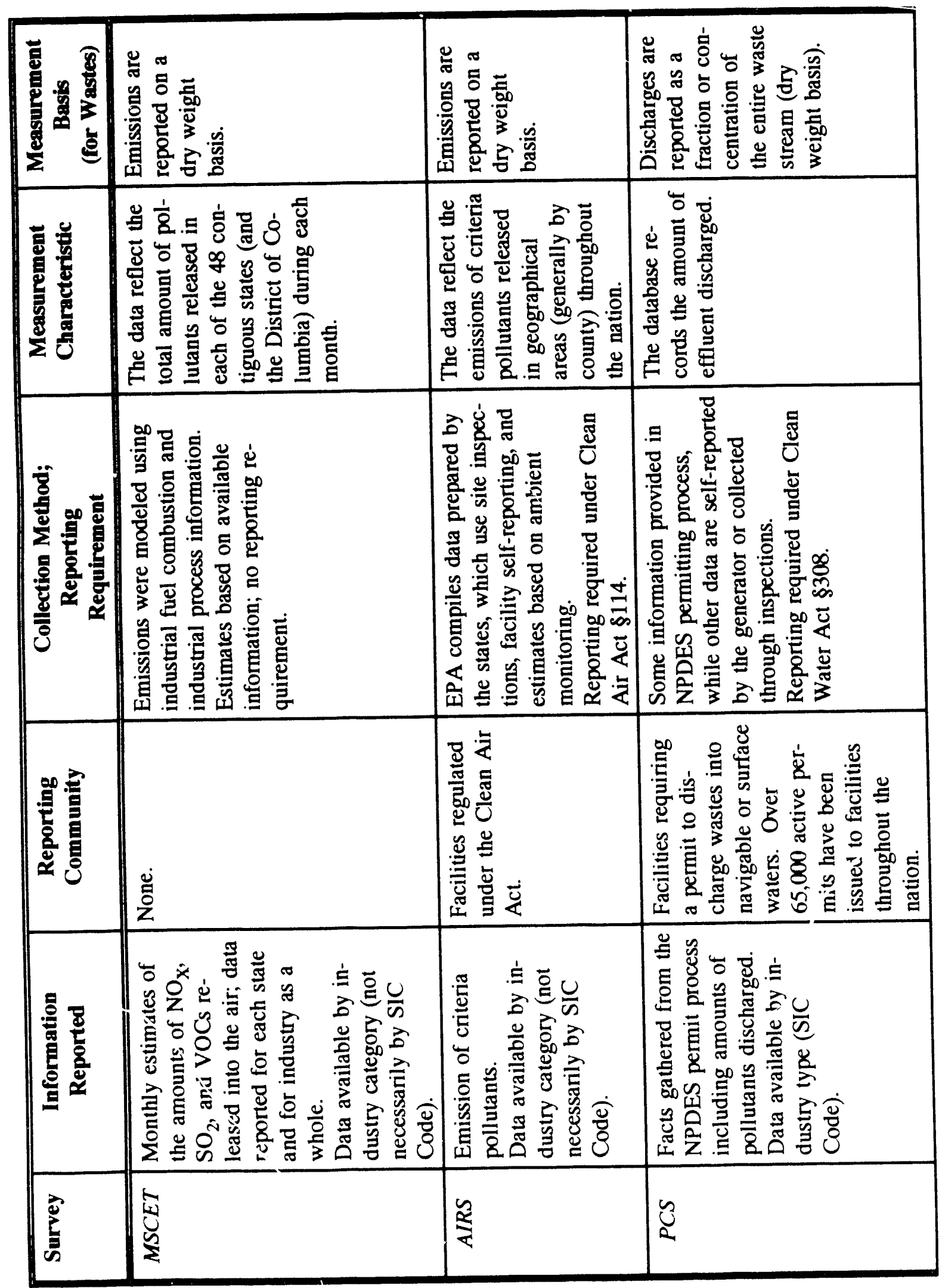

Characterization of Waste Data Sources 


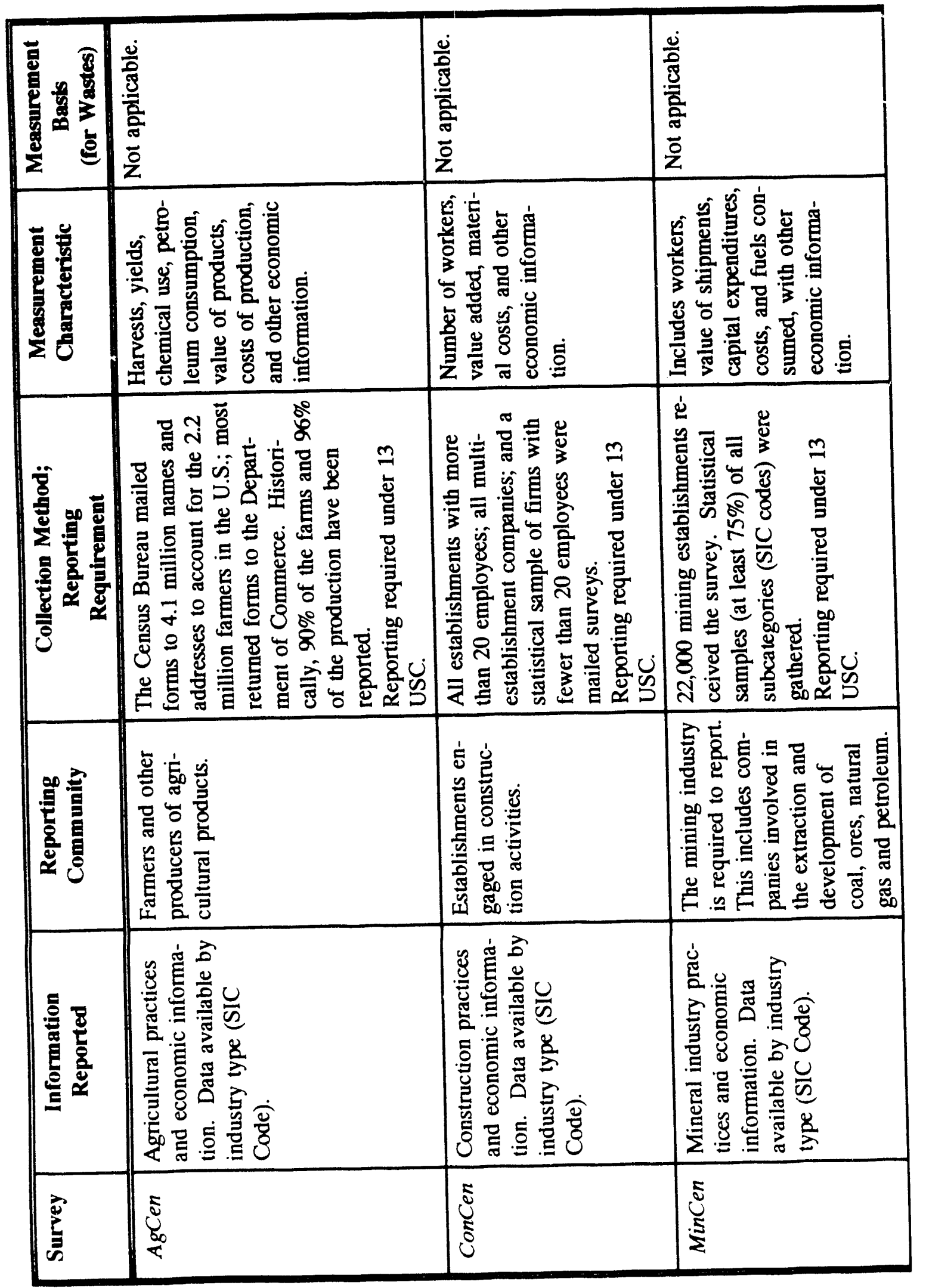

Characterization of Waste Data Sources

22

September 3, 1991 


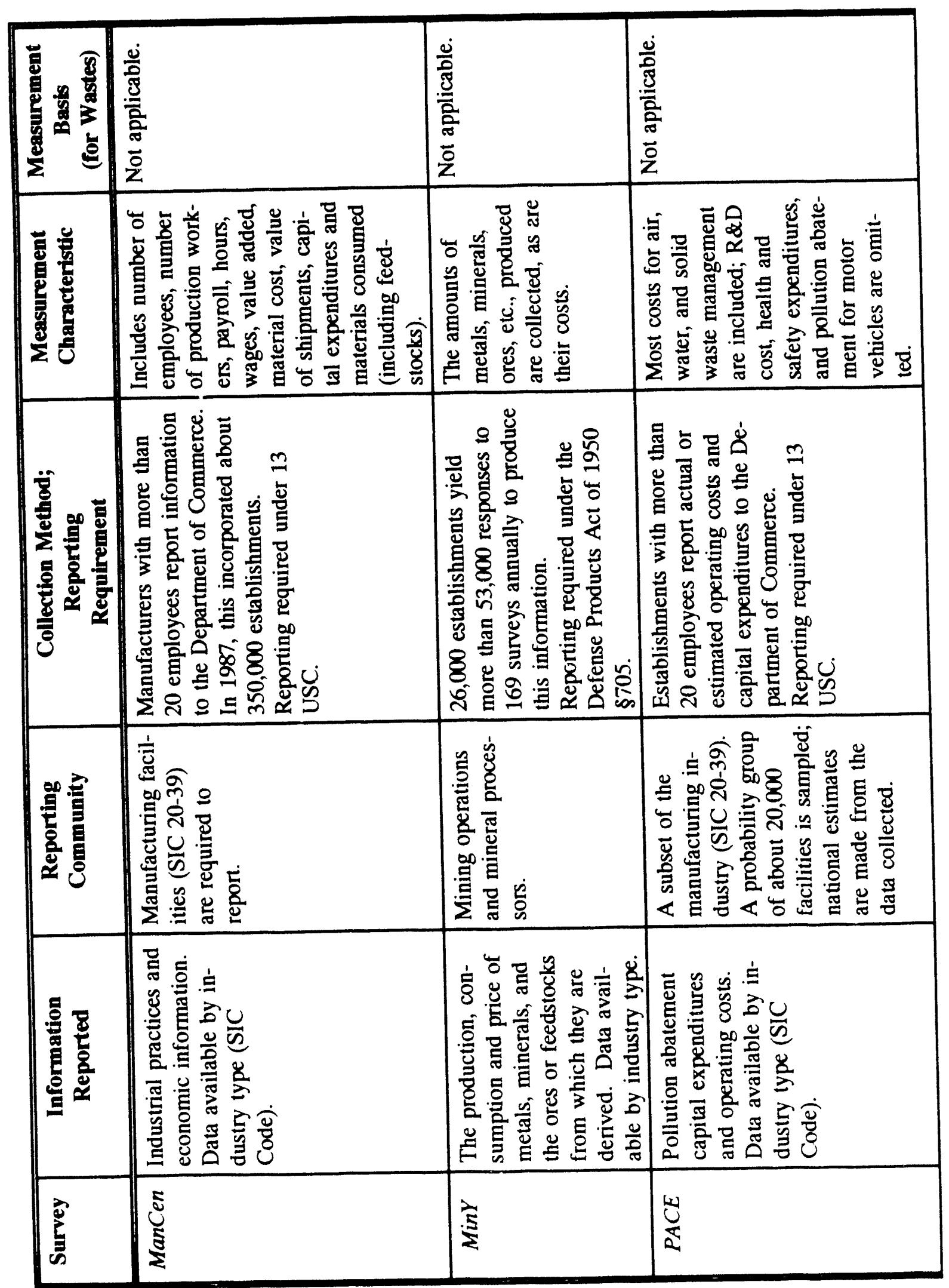

Characterization of Waste Data Sources 


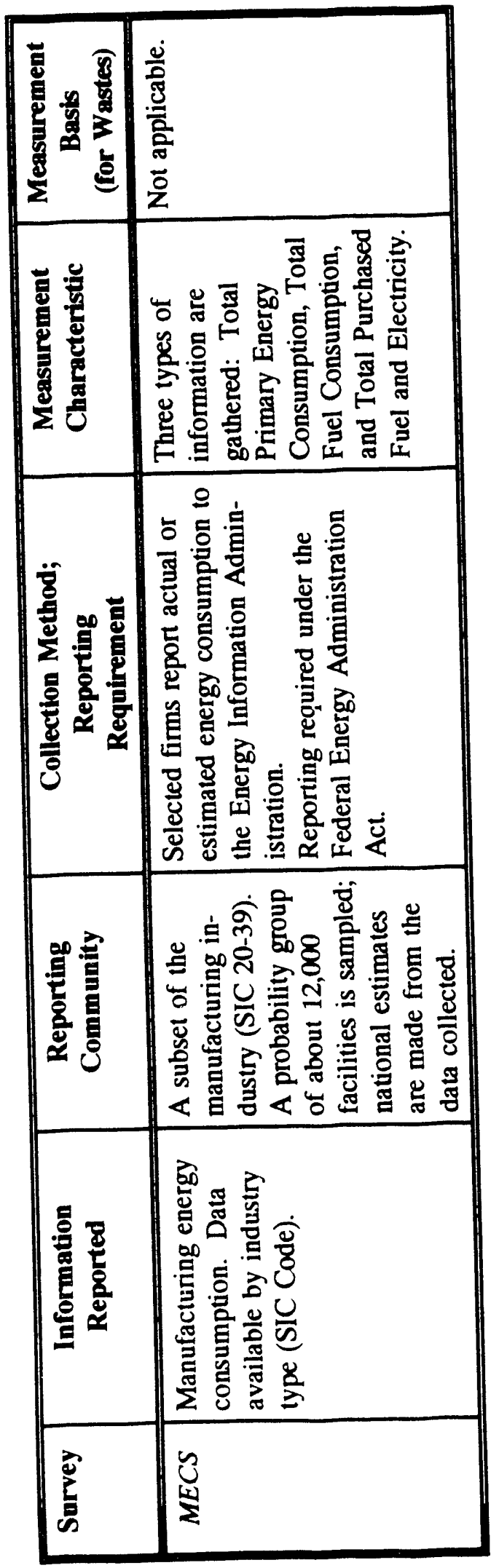




\section{CONCLUSIONS}

While a wealth of data is collected on various industrial waste streams, the type of data collected and the way it is collected have obvious shortcomings. Although EPA is the closest to being a centralized agency for waste data collection, the agency appears to have neither the mandate nor the resources to undertake this role. Furthermore, a balance must be struck between gathering more comprehensive and accurate data and overburdening industry with mountains of reporting requirements.

The most significant difficulties with the data on waste generation include the following:

- The definition of waste is not consistent throughout all data sources. For example, though the EPA definition of hazardous solid waste is recognized by all sources, a number of sources include discharges governed by the Clean Water Act. The RCRA-regulated wastes are not usually split out to allow easy comparison to EPA figures.

- $\quad$ EPA produced many of these studies, and their interest is on post-plant pollutants rather than process wastes. Hence, quantities of wastes treated or discarded are recorded rather than amounts of wastes generated. In addition, their studies tend to neglect nonhazardous wastes and other wastes not considered harmful.

- While a number of sources present hazardous waste data, no single source presents all releases of all wastes, hazardous or otherwise. The Toxics Release Inventory presents information on releases to air, water, and land, but it does so only for a limited number of chemicals, rather than for all hazardous wastes. All other reports present only releases to air, water, or land.

The Biennial Survey reports only RCRA-regulated wastes, so discharges to air and water are omitted. Similarly, the PCS database records only NPDES discharges, omitting air and solid wastes. The AIRS database contains information on only air pollutants -- and just a limited number of those. Trying to combine the three is difficult as well, because the data in each system are retrieved in different ways. Because wastes are regulated differently under RCRA, the Clean Air Act, and the Clean Water Act, the methods of collecting and analyzing the data vary.

- Many of the surveys required facility personnel to estimate quantities of waste. Since the estimating capabilities of individuals differ, it is likely that many of the data are inaccurate. In addition, some of the estimating techniques used by the organization reporting the data may lead to errors. CBO's method of correlating industrial output to the number of employees seems unlikely, at least on a small scale, while EPA's method of estimating oil and gas waste by the volume of the pit may also cause data flaws.

- Many of the data presented on air pollutants from point sources rely on estimates rather than direct measurements. Since processes vary in their efficiencies and plants vary in their containment of volatile chemicals, discharges from specific plants or types of plants are difficult to gauge accurately.

- Information on nonhazardous waste is not collected on a regular basis, either by the Federal government or by industry groups. Most of the information that has been gathered reflects only a snapshot of conditions at a given time. 
- EPA's reports on nonhazardous waste do not include agricultural or construction wastes. Because these pose a very low risk to health and the environment, EPA has little concern for them. There may be sources of data that provide estimates of these.types of waste, but it is unlikely that a detailed national survey has been undertaken.

- No waste data studied in this report are correlated to production levels.

In general, the problems associated with the collection waste data do not exist with the economic information accumulated by the Bureau of the Census and the Bureau of Mines or the energy data reported by the Energy Information Administration. These data are, however, limited as well; the economic data are handicapped since no direct measure of economic output exists, while the Manufacturing Energy Consumption Survey lacks detailed information on biomass and solar energy consumption and is restricted to the manufacturing industry.

Nevertheless, the data examined in this report do, however, provide a starting point from which to improve data collection and analysis methods. If industrial waste reduction is to become a successful approach to waste management, different information will need to be collected. Distinctions between hazardous and nonhazardous wastes may become less important as their definitions change. One thing remains clear: measurable progress on waste reduction will require more complete and reliable data. 


\section{APPENDIX A: DATA SOURCES NOT INCLUDED}

In addition to the sources reviewed in the main body of this paper, a number of data sources were considered in a preliminary screening. These sources are listed here, preceded by the reason they were not included in the report.

The following documents contain data that were superseded by more recent or more thorough data presented in sources examined in the report.

EIA 1988. Manufacturing Energy Consumption Survey: Consumption of Energy, 1985. DOE/EIA0512(85). Energy Information Administration, U.S. Department of Energy. Washington, D.C.

EPA 1984. National Survey of Hazardous Waste Generators and Treatment, Storage, and Disposal Facilities Regulated Under RCRA in 1981. EPA/530-SW-84-005. Prepared by Westat, Inc. for U.S. Environmental Protection Agency. Washington, D.C.

EPA 1987. National Air Pollutant Emission Estimates: 1940-1985. U.S. Environmental Protection Agency. Research Triangle Park, NC.

EPA 1988. National Screening Survey of Hazardous Wasie Treatment, Storage, Disposal, and Recycling Facilities, 1986. EPA/530-SW-88-035. Office of Solid Waste, U.S. Environmental Protection Agency. Washington, D.C.

EPA 1989. 1985 National Report of Hazardous Waste Generators and Treatment, Storage, and Disposal Facilities Regulated Under RCRA. Office of Solid Waste, U.S. Environmental Protection Agency. Washington, D.C.

EPA 1989. The Toxics Release Inventory: A National Perspective, 1987. U.S. Environmental Protection Agency. Washington, D.C.

Farber, Kit D., and Gary L. Rutledge. 1989. "Pollution Abatement and Control Expenditures, 19841987." Survey of Current Business. June, 1989, pp. 19-25.

Two data sources were secondary sources. The data they contain were previously reported in another document.

EPA 1985. Report to Congress: Wastes from the Extraction and Beneficiation of Metallic Ores, Phosphate Rock, Asbestos, Overburden from Uranium Mining and Oil Scale. U.S. Environmental Protection Agency. Washington, D.C.

EPA 1986. Report to Congress on the Discharge of Hazardous Waste to Publicly Owned Treatment Works. EPA 530/SW-86-004. Office of Solid Waste, U.S. Environmental Protection Agency. Washington, D.C. 
1. OTA 1986.

2. EPA $1987 b$.

3. EPA 1988.

4. EPA 1991c.

5. EPA $1991 \mathrm{~b}$.

6. CMA 1990.

7. API 1991.

8. EPA $1990 \mathrm{f}$.

9. CBO 1985.

10. EPA 1987b.

11. EPA 1988.

12. EPA 1987a.

13. EPA 1990e.

14. EPA 1991a.

15. ANL 1990.

16. EIA 1975-1988.

17. DOC 1985-1988.

18. DOC 1990a.

19. DOC $1990 \mathrm{~b}$.

20. DOC 1990d.

21. DOC 1990c.

22. DOI 1990.

23. DOC 1990e.

24. EIA 1991. 


\section{ACRONYMS AND ABBREVIATIONS}

AgCen

AIRS

ANL

API

APISur

BR

BRS

CBO

CBOEst

CMA

CMASur

$\mathrm{CO}$

ConCen

DOC

DOE

DOI

EIA

EPA

FOIA

IWRP

ManCen

MECS

MinCen

MinY

MSCET

NAPAP

NAPEE

NatSur

$\mathrm{NO}_{X}$

NPDES

O\&G
1987 Census of Agriculture (the Agriculture Census)

Aerometric Information Retrieval System database

Argonne National Laboratory

American Petroleum Institute

The Generation and Management of Wastes and Secondary Materials in the Petroleum Refining Industry (the API survey)

1987 National Biennial Report of Hazardous Waste Treatment, Storage, and Disposal Facilities Regulated under RCRA (the Biennial Report)

Biennial Reporting System database

Congressional Budget Office

Hazardous Waste Management: Recent Changes and Policy Alternatives (the CBO estimates)

Chemical Manufacturers' Association

CMA Hazardous Waste Survey '88 (the CMA survey)

Carbon Monoxide

1987 Census of Construction Industries (the Construction Census)

U.S. Department of Commerce

U.S. Department of Energy

U.S. Department of the Interior

DOE's Energy Information Administration

U.S. Environmental Protection Agency

Freedom of Information Act

OIT's Industrial Waste Reduction Program

1987 Cerisus of Manufactures - Industry Series (the Manufacturing Census)

Manufacturing Energy Consumption Survey: Consumption of Energy, 1985

1987 Census of Mineral Industries (the Mining, Census)

Minerals Yearbook 1988. Volume 1. Metals and Minerals. (the Minerals Yearbook)

Month and State Current Emission Trends survey

National Air Precipitation Assessment Program

National Air Pollutant Emission Estimates: 1940.1989

National Survey of Hazardous Waste Generators and Treatment, Storage, Disposal, and Recycling Facilities, 1986 (the National Survey)

Nitrogen Oxides

National Pollutant Discharge Elimination System

Report to Congress: Management of Wastes from the Exploration, Development, and Production of Crude Oil, Natural Gas, and Geothermal Energy. Volume 1. Oil and Gas. (the Oil \& Gas survey) 
OIT

OTA

PACE

$\mathrm{Pb}$

PCS

RCRA

R\&D

SIC

SMP

$\mathrm{SO}_{2}$

SubD

TOXNET

TRI

TRISur

TSDF

VOC
DOE's Office of Industrial Technologies (in the Office of Conservation and Renewable Energy)

Office of Technology Assessment

Manufacturer's Pollution Abatement Capital Expenditures and Operating Costs: Final Repori for 1988

Lead

Permit Compliance System database

Resource Conservation and Recovery Act

Research and Development

Standard Industrial Classification

Report to Congress on Special Wastes from Mineral Processing

Sulfur Dioxide

Screening Survey of Industrial Subtitle D Establishments: Draft Final Report (the Subtitle D survey)

The National Library of Medicine's on-line database; contains the Toxics Release Inventory

Toxics Release Inventory

Printed version of the Toxics Release Inventory (the TRI survey)

Treatment, Storage, and Disposal Facility

Volatile Organic Compound 


\section{REFERENCES}

ANL 1990. Current Emission Trends for Nitrogen Oxides, Sulfur Dioxides, and Volatile Organic Compounds by Month and State: Methodology and Results. Argonne National Laboratory, U.S. Department of Energy. Argonne, Illinois.

API 1991. The Generation and Management of Wastes and Secondary Materials in the Petroleum Refining Industry. API Publication Number 4530. American Petroleum Institute. Washington, D.C.

CBO 1985. Hazardous Waste Management: Recent Changes and Policy Alternatives. Congressional Budget Office, Congress of the United States. Washington, D.C.

CMA 1990. CMA Hazardous Waste Survey '88. Prepared by Tischler/Kocurek, Inc. for the Chemical Manufacturer's Association. Washington, D.C.

DHS 1988. Economic Implications of Waste Reduction, Recycling, Treatment, and Disposal of Hazardrus Waste: Fourth Biennial Report. California Department of Health Services, July 1988.

DOC 1985-1988. Survey of Current Business Monthly Statistics. Bureau of Economic Analysis, U.S. Department of Commerce. Washington, D.C.

DOC 1990a. 1987 Census of Agriculture. AC-87-A. Bureau of the Census, U.S. Department of Commerce. Washington, D.C.

DOC 1990b. 1987 Census of Construction Industries. CC87-I. Bureau of the Census, U.S. Department of Commerce. Washington, D.C.

DOC 1990c. 1987 Census of Manufactures - Industry Series. MC87-I. U.S. Department of Commerce, Bureau of the Census. Washington, D.C.

DOC 1990d. 1987 Census of Mineral Industries. MIC87-I. Bureau of the Census, U.S. Department of Commerce. Washington, D.C.

DOC 1990e. Manufacturer's Pollution Abatement Capital Expenditures and Operating Costs. MA200(88)-1. Bureau of the Census, U.S. Department of Commerce. Washington, D.C.

DOC 1990f. Statistical Abstract of the United States. U.S. Department of Commerce, Bureau of the Census. Washington, D.C.

DOI 1990. Minerals Yearbook 1988. Volume 1. Metals and Minerals. Bureau of Mines, U.S. Department of the Interior. Washington, D.C.

EIA 1975-1988. Monthly Energy Review. DOE/EIA-0035. Energy Information Administration, U.S. Department of Energy. Washington, D.C.

EIA 1991. Manufacturing Energy Consumption Survey: Consumption of Energy, 1988. DOE/EIA0512(88). Energy Information Administration, U.S. Department of Energy. Washington, D.C. 
EPA 1985. Summary of Data on Industrial Non-Hazardous Waste Disposal Prartices. EPA Contract No. 68-01-7050, Work Assignment No. 11. U.S. Environmental Protection Agency. Washington, D.C.

EPA 1986. Waste Minimization: Issues and Options. EPA Contract No. 68-01-7053, Task No. 17. Prepared for the U.S. Environmental Protection Agency by Versar, Inc., and Jacobs Engineering Group. Washington, D.C.

EPA 1987a. Report to Congress: Management of Wastes from the Exploration Development, and Production of Crude Oil, Natural Gas, and Geothermal Energy, Vol. 1: Oil and Gas. EPA/530-SW-88003A. Prepared by Versar, Inc., for the U.S. Environmental Protection Agency. Washington, D.C.

EPA 1987b. Results of the Industrial Subtitle D Facility Survey. Unpublished. Office of Solid Waste, U.S. Environmental Protection Agency. Washington, D.C.

EPA 1988. Report to Congress: Solid Waste Disposal in the United States, Volumes 1 and 2. EPA/530SW-88-011. Office of Solid Waste and Emergency Response, U.S. Environmental Protection Agency. Washington, D.C.

EPA 1989. Information Resources Directory. OCPA 19M-4001. Office of Administration and Resources Management, U.S. Environmental Protection Agency. Washington, D.C.

EPA 1990a. A Catalog of Hazardous and Solid Waste Publications. EPA/530/SW-90-052. U.S. Environmental Protection Agency, Washington, D.C.

EPA 1990b. Environmental Investments: The Cost of a Clean Environment. EPA-230-12-90-084. Office of Policy, Planning and Evaluation, U.S. Environmental Protection Agency. Washington, D.C.

EPA 1990c. Environmental Statistics in the U.S. Government. Computer disk prepared for the EPA Center for Environmental Statistics, U.S. Environmental Protection Agency, by Folio Corporation. Provo, Utah.

EPA 1990d. Headquarters Telephone Directory. Office of Administration and Resources Management, U.S. Environmental Protection Agency. Washington, D.C.

EPA 1990e. Report to Congress on Special Wastes from Mineral Processing: Summary and Findings Methods and Analyses Appendices. EPA/530-SW-90-70C. U.S. Environmental Protection Agency, Washington, D.C.

EPA 1990f. Toxics in the Community: National and Local Perspectives. EPA/560/4-90-017. Office of Pesticides and Toxic Substances, U.S. Environmental Protection Agency. Washington, D.C.

EPA 1991a. National Air Pollutant Emission Estimates: 1940-1989. EPA-450/4-91-004. Office of Air Quality, U.S. Environmental Protection Agency. Research Triangle Park, NC.

EPA 1991b. National Survey of Hazardous Waste Generators and Treatment, Storage, Disposal, and Recycling Facilities, 1986. EPA/530-SW-91-060. Office of Solid Waste, U.S. Environmental Protection Agency. ashington, D.C. 
EPA 1991c. 1987 National Report of Hazardous Waste Generators and Treatment, Storage, and Disposal Facilities Regulated Under RCRA. EPA/530-SW-91-061. Office of Solid Waste, U.S. Environmental Protection Agency. Washington, D.C.

HWRIC 1990. Industrial Waste Reduction: State Policy Options. P.A. 85-1196. Illinois Department of Energy and Natural Rcsources, Hazardous Waste Research and Information Center. Chicago, Illinois.

Olson, R. J., 1984. Review of Existing Environmental and Natural Resource Data Bases. ORNL/TM8928. Oak Ridge National Laboratory, U.S. Department of Energy. Oak Ridge, TN.

OTA 1986. Serious Reduction of Hazardous Waste for Pollution Prevention and Industrial Efficiency. OTA-ITE-317. Office of Technology Assessment, U.S. Congress. Washington, D.C. 

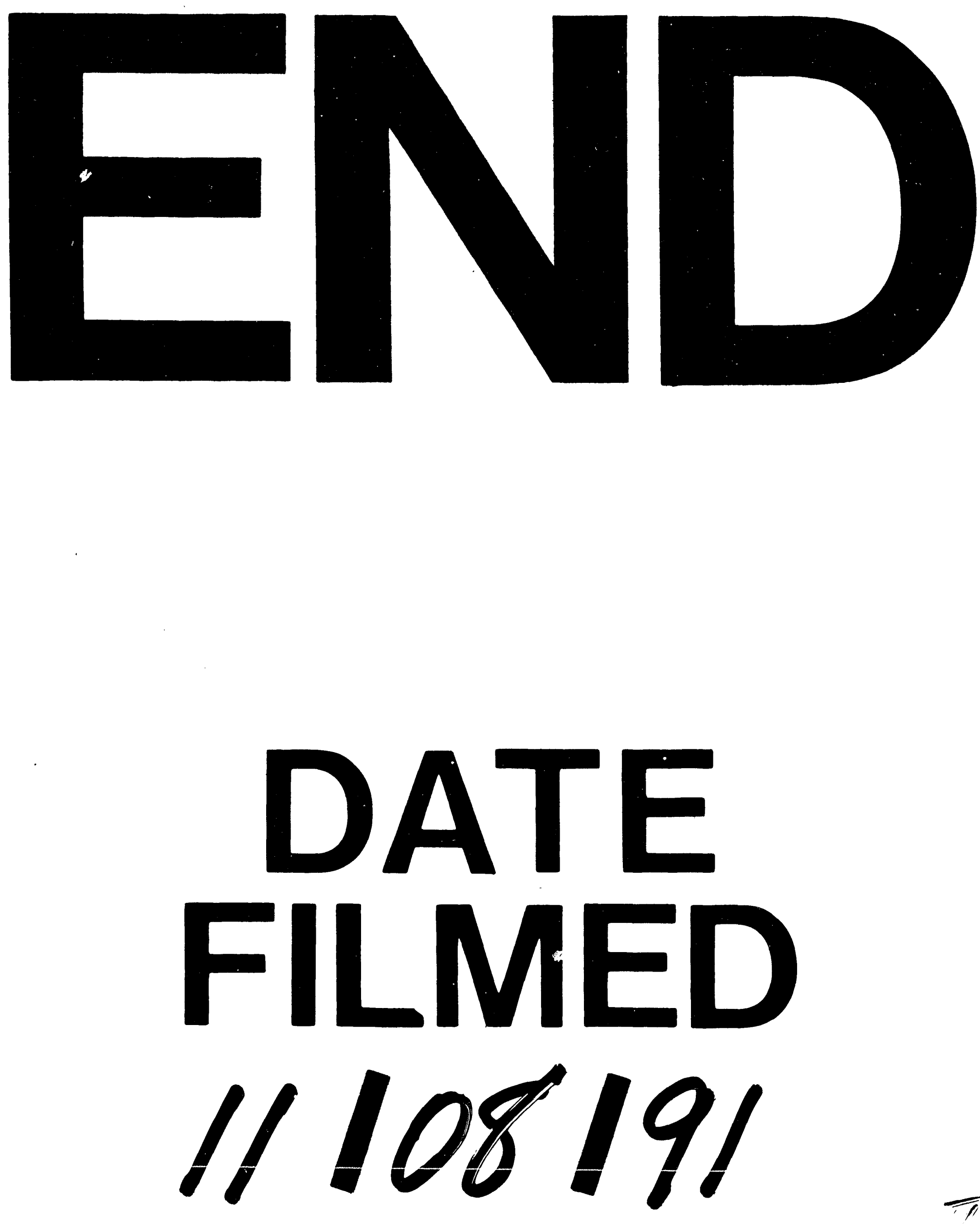
